\title{
Airborne DOAS retrievals of methane, carbon dioxide, and water vapor concentrations at high spatial resolution: application to AVIRIS-NG
}

\author{
Andrew K. Thorpe ${ }^{1}$, Christian Frankenberg ${ }^{2,1}$, David R. Thompson $^{1}$, Riley M. Duren ${ }^{1}$, Andrew D. Aubrey ${ }^{1}$, \\ Brian D. Bue ${ }^{1}$, Robert O. Green ${ }^{1}$, Konstantin Gerilowski ${ }^{3}$, Thomas Krings ${ }^{3}$, Jakob Borchardt ${ }^{3}$, Eric A. Kort ${ }^{4}$, \\ Colm Sweeney $^{5}$, Stephen Conley ${ }^{6,7}$, Dar A. Roberts ${ }^{8}$, and Philip E. Dennison ${ }^{9}$ \\ ${ }^{1}$ Jet Propulsion Laboratory, California Institute of Technology, Pasadena, California, USA \\ ${ }^{2}$ Division of Geological and Planetary Sciences, California Institute of Technology, Pasadena, California, USA \\ ${ }^{3}$ Institute of Environmental Physics (IUP), University of Bremen, Bremen, Germany \\ ${ }^{4}$ Department of Climate and Space Sciences and Engineering, University of Michigan, Ann Arbor, Michigan, USA \\ ${ }^{5}$ Cooperative Institute for Research in Environmental Sciences, University of Colorado, Boulder, Colorado, USA \\ ${ }^{6}$ Global Monitoring Division, NOAA Earth System Research Laboratory, Boulder, Colorado, USA \\ ${ }^{7}$ Scientific Aviation, 3335 Airport Road, Boulder, Colorado, USA \\ ${ }^{8}$ Department of Geography, University of California, Santa Barbara, Santa Barbara, California, USA \\ ${ }^{9}$ Department of Geography, University of Utah, Salt Lake City, Utah, USA \\ Correspondence to: Andrew K. Thorpe (andrew.k.thorpe@jpl.nasa.gov)
}

Received: 18 February 2017 - Discussion started: 9 May 2017

Revised: 29 August 2017 - Accepted: 5 September 2017 - Published: 19 October 2017

\begin{abstract}
At local scales, emissions of methane and carbon dioxide are highly uncertain. Localized sources of both trace gases can create strong local gradients in its columnar abundance, which can be discerned using absorption spectroscopy at high spatial resolution. In a previous study, more than 250 methane plumes were observed in the San Juan Basin near Four Corners during April 2015 using the next-generation Airborne Visible/Infrared Imaging Spectrometer (AVIRISNG) and a linearized matched filter. For the first time, we apply the iterative maximum a posteriori differential optical absorption spectroscopy (IMAP-DOAS) method to AVIRISNG data and generate gas concentration maps for methane, carbon dioxide, and water vapor plumes. This demonstrates a comprehensive greenhouse gas monitoring capability that targets methane and carbon dioxide, the two dominant anthropogenic climate-forcing agents. Water vapor results indicate the ability of these retrievals to distinguish between methane and water vapor despite spectral interference in the shortwave infrared. We focus on selected cases from anthropogenic and natural sources, including emissions from mine ventilation shafts, a gas processing plant, tank, pipeline leak, and natural seep. In addition, carbon dioxide emissions were
\end{abstract}

mapped from the flue-gas stacks of two coal-fired power plants and a water vapor plume was observed from the combined sources of cooling towers and cooling ponds. Observed plumes were consistent with known and suspected emission sources verified by the true color AVIRIS-NG scenes and higher-resolution Google Earth imagery. Real-time detection and geolocation of methane plumes by AVIRIS-NG provided unambiguous identification of individual emission source locations and communication to a ground team for rapid follow-up. This permitted verification of a number of methane emission sources using a thermal camera, including a tank and buried natural gas pipeline.

\section{Introduction}

It is important to better understand the processes controlling changes in atmospheric methane $\left(\mathrm{CH}_{4}\right)$ and carbon dioxide $\left(\mathrm{CO}_{2}\right)$, the two dominant anthropogenic climate-forcing agents. $\mathrm{CH}_{4}$ and $\mathrm{CO}_{2}$ contribute approximately 17 and $64 \%$ of the total radiative forcing attributed to anthropogenic 
greenhouse gases and halocarbons (Myhre et al., 2013). The atmospheric growth rates are strongly influenced by anthropogenic emissions of $\mathrm{CH}_{4}$ and dominated by fossil fuel $\mathrm{CO}_{2}$ emissions. Anthropogenic $\mathrm{CH}_{4}$ sources were estimated to contribute $10.6 \%$ of the total 2014 anthropogenic emissions of the United States, with major sources including natural gas systems $(2.6 \%)$, enteric fermentation $(2.4 \%)$, landfills $(2.2 \%)$, petroleum systems $(1.0 \%)$, and coal mining (1.0\%) (EPA, 2016a). $\mathrm{CH}_{4}$ is a precursor for tropospheric ozone and is strongly linked with co-emitted reactive trace gases that are the focus of air quality mitigation policies. US anthropogenic $\mathrm{CO}_{2}$ sources make up $81 \%$ of the total anthropogenic emissions and are dominated by fossil fuel combustion, including electricity generation (30\%), transportation $(25 \%)$, and industrial emissions (12\%) (EPA, 2016a). US emissions of both gases are projected to increase (EIA, 2013) and a number of studies have suggested that EPA bottom-up emission inventories are underestimated for $\mathrm{CH}_{4}$ (Miller et al., 2013; Wecht et al., 2014; Turner et al., 2015). US fossil fuel $\mathrm{CO}_{2}$ emissions are better constrained through existing inventories of fossil fuel sales and combustion, but global uncertainties are growing with the rise of a number of large developing countries where emissions information is not readily available (NRC, 2010; Ballantyne et al., 2015; Ciais et al., 2015).

There remains uncertainty regarding the sources and sinks of atmospheric $\mathrm{CH}_{4}$, as reflected by the ongoing scientific discussion on both the hiatus in the atmospheric growth rate in the early 21 st century and the unexpected rise starting in 2007 (Nisbet et al., 2014). Further, regional top-down emissions estimates cannot discriminate source categories and thereby attribute fluxes to specific processes or sources. Uncertainty in anthropogenic $\mathrm{CH}_{4}$ emissions is large at multiple scales and process attribution remains challenging because emissions originate from biological processes, venting, and leaks (Kirschke et al., 2013; Schwietzke et al., 2016; Schaefer et al., 2016).

Recent studies suggest that the majority of $\mathrm{CH}_{4}$ emissions from oil and gas supply chains are caused by a number of super-emitters, which could explain underestimates in bottom-up inventories (Zavala-Araiza et al., 2015; Lyon et al., 2015; Brandt et al., 2014, 2016). The ability to identify emission sources offers the potential to constrain regional greenhouse gas budgets and improve partitioning between anthropogenic and natural emission sources. Although $\mathrm{CH}_{4}$ has a short atmospheric lifetime (about 9 years), it has a very high global warming potential (GWP) that is 86 times greater than $\mathrm{CO}_{2}$ on a 20 year timescale (Myhre et al., 2013). This means that even small amounts of emissions reduction will result in large reductions in the overall atmospheric radiative forcing.

Driving surveys using in situ instruments have been used to identify $\mathrm{CH}_{4}$ emission sources in major US metropoli$\tan$ areas like the Los Angeles basin (Hopkins et al., 2016), Boston (Phillips et al., 2013), and Washington, D.C. (Jackson et al., 2014), as well as to measure fluxes (Rella et al., 2015).
Recently, ground-based thermal imaging systems have also been used to identify $\mathrm{CH}_{4}$ emissions (Johnson et al., 2015; Galfalk et al., 2016). However, these methods require comprehensive sampling techniques, are time consuming, and can be limited to regions with sufficient road access. In situ airborne measurements offer the potential for increased coverage and have been used for US regional $\mathrm{CH}_{4}$ flux estimates using mass balance approaches for the Uintah Basin in northeastern Utah (Karion et al., 2013), the Marcellus formation in southwestern Pennsylvania (Caulton et al., 2014), and the Barnett Shale formation in Texas (Smith et al., 2015; Lavoie et al., 2015). These measurements reflect gas concentrations at the flight altitude and these studies are designed to estimate aggregate emissions for large regions rather than identifying individual emissions sources.

More recently, in situ airborne measurements using a chemically instrumented Mooney aircraft have been used to estimate fluxes from known sources like the Aliso Canyon leak (Conley et al., 2016) and for a number of sources identified by imaging spectrometers in the Four Corners region (Frankenberg et al., 2016). This method samples the atmosphere directly at the flight path altitude and can measure multiple gas species. The Methane Airborne MAPper (MAMAP) spectrometer (Gerilowski et al., 2011) has also been used to measure elevated $\mathrm{CH}_{4}$ and $\mathrm{CO}_{2}$ column abundances to quantify emissions from a coal mine ventilation shaft (Krings et al., 2013), power plants (Krings et al., 2011), and a landfill (Krautwurst et al., 2017). MAMAP is a nonimaging spectrometer with a small field of view limited to flying transects across gas plumes rather than quickly mapping their morphology and extent on small scales. Both instruments are better suited for either investigating known emission sources or identifying larger regional emissions as opposed to individual sources.

\section{Airborne imaging spectrometers}

Airborne imaging spectrometers like the Airborne Visible/Infrared Imaging Spectrometer (AVIRIS) (Green et al., 1998) and the next-generation instrument AVIRIS-NG (Hamlin et al., 2011) can map large regions while providing the spatial resolution required to identify individual emissions within scenes. While not originally designed for mapping emissions, these instruments measure the 0.38 to $2.5 \mu \mathrm{m}$ range, which includes many gas absorption features (Fig. 1). This has permitted quantitative retrievals of $\mathrm{CH}_{4}$ using AVIRIS (approximately $10 \mathrm{~nm}$ spectral resolution and sampling) for marine seeps (Roberts et al., 2010; Thorpe et al., 2014). Water vapor retrievals have been demonstrated with AVIRIS (Gao and Goetz, 1990; Thompson et al., 2015a) mainly for atmospheric correction and reflectance retrievals. However, AVIRIS water vapor retrievals have also been used to measure plant transpiration, demonstrating potential appli- 

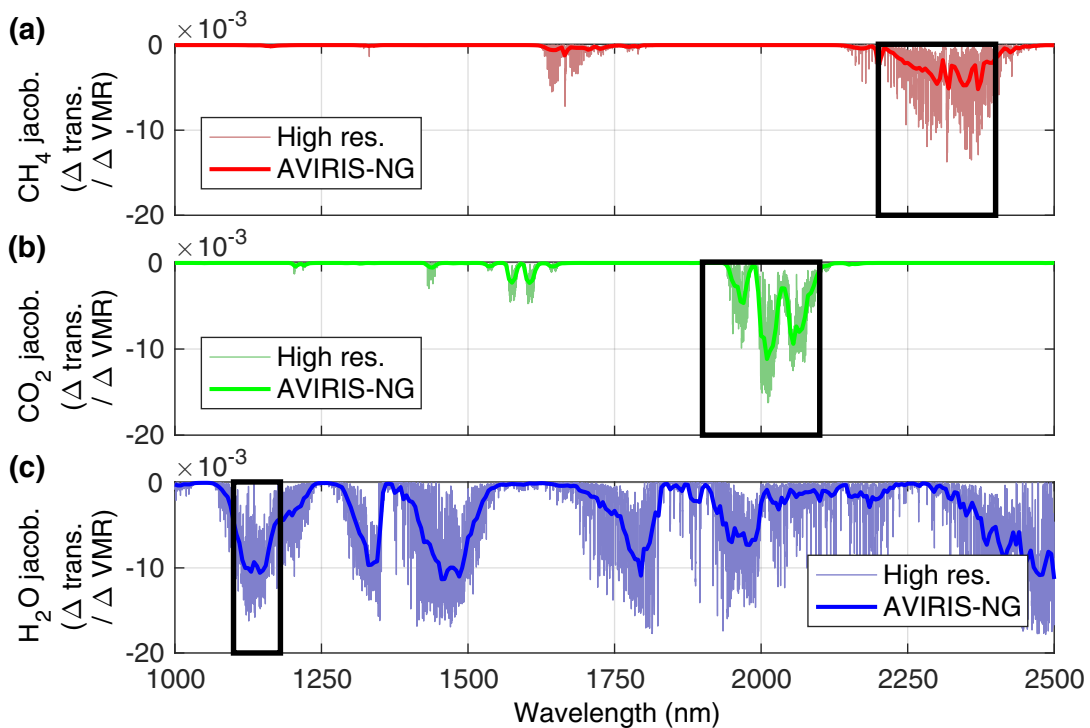

Figure 1. High-resolution gas Jacobians plotted in lighter colors and for AVIRIS-NG ( $5 \mathrm{~nm}$ spectral resolution and sampling) for (a) $\mathrm{CH}_{4}$ (red), (b) $\mathrm{CO}_{2}$ (green), and (c) $\mathrm{H}_{2} \mathrm{O}$ (blue). These examples were calculated for a $5 \%$ change in $\mathrm{CH}_{4}$ (red), (b) $\mathrm{CO}_{2}$ (green), and (c) $\mathrm{H}_{2} \mathrm{O}$ over the total column. AVIRIS-NG retrieval windows are indicated by the black outlines.

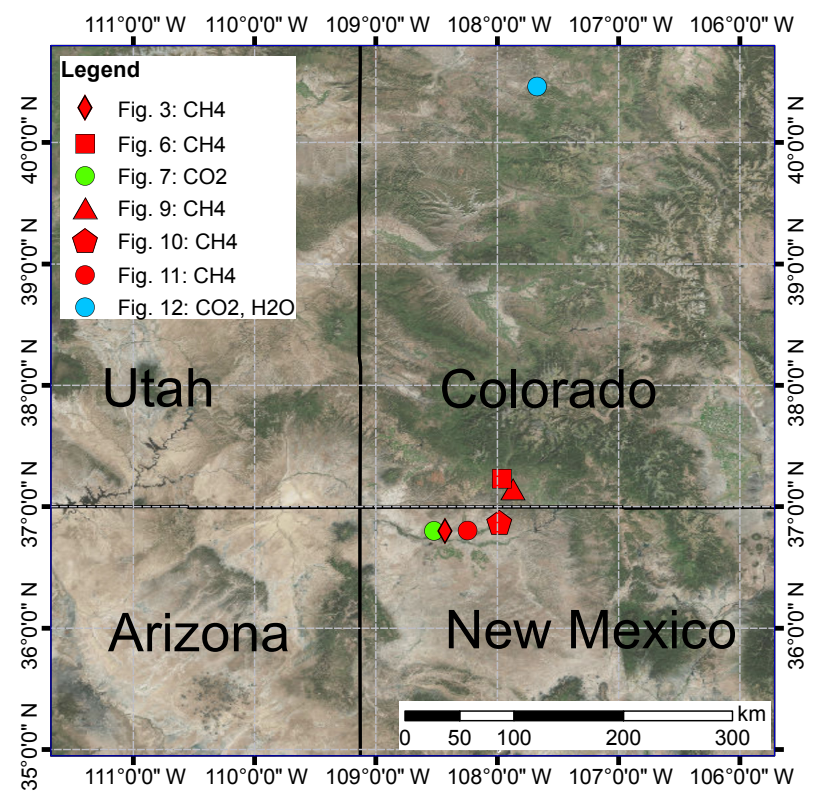

Figure 2. Locations of gas plumes presented in this study.

cation to the fields of ecology and meteorology (Ogunjemiyo et al., 2002).

AVIRIS has been used for high-resolution mapping of $\mathrm{CO}_{2}$ plumes from industrial sources (Dennison et al., 2013) and wildfires (Marion et al., 2004; Deschamps et al., 2011). More recently, AVIRIS-NG (approximately $5 \mathrm{~nm}$ spectral resolution and sampling) has surveyed large regions to identify $\mathrm{CH}_{4}$ emissions associated with oil production (Thompson et al., 2015b), gas extraction (Frankenberg et al., 2016), hydraulic fracturing (Aubrey et al., 2015), and a landfill (Krautwurst et al., 2017). This is possible due to a $34^{\circ}$ field of view, which results in an image swath of $1.8 \mathrm{~km}$ when flying at $3 \mathrm{~km}$ a.g.l. (above ground level).

Airborne imaging spectrometers that operate in the thermal infrared, such as the Mako and HyTES instruments (Tratt et al., 2014; Hulley et al., 2016), have also been used for mapping $\mathrm{CH}_{4}$ plumes. However, the altitude of maximum sensitivity varies with environmental conditions like thermal contrast (Kuai et al., 2016), which can make plumes difficult to detect and quantify, and sensitivity to near-surface emissions decreases with flight altitude, which can limit ground coverage. Because AVIRIS and AVIRIS-NG measure reflected solar radiation in the shortwave infrared, $\mathrm{CH}_{4}$ retrieval sensitivity is impacted only slightly by flight altitude due to additional gas attenuation along the optical path. However, at higher flight altitude and coarser spatial resolution a gas enhancement is diluted over a larger image pixel, thereby decreasing instrument sensitivity. The ability to fly high results in more efficient flight campaigns due to improved ground coverage. For example, AVIRIS-NG consistently observed plumes for a $\mathrm{CH}_{4}$ controlled release experiment for all altitudes flown (up to $3.8 \mathrm{kma.g} .1$.) and AVIRIS has observed $\mathrm{CH}_{4}$ plumes flying at $8.9 \mathrm{kma}$.g.l. (Thorpe et al., 2014). AVIRIS has also mapped $\mathrm{CH}_{4}$ plumes over multiple days from the Aliso Canyon leak by flying $6.6 \mathrm{~km}$ a.g.l., resulting in an image swath approximately $4.0 \mathrm{~km}$ wide (Thompson et al., 2016). This also offers the potential for space-based detection of emission sources, like the observed $\mathrm{CH}_{4}$ plume from Aliso Canyon using the orbital Hyperion imaging spectrometer (Thompson et al., 2016). 
(a) 20 April 2015, 18:06:24 UTC

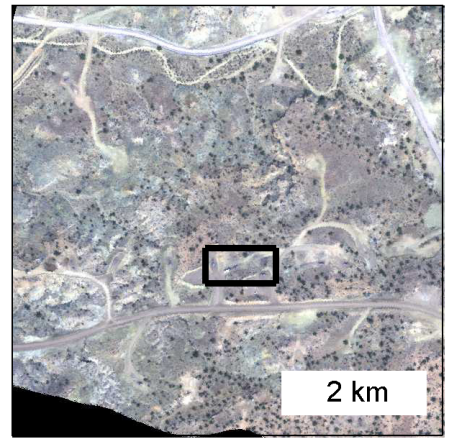

(c) 20 April 2015, 18:06:24 UTC

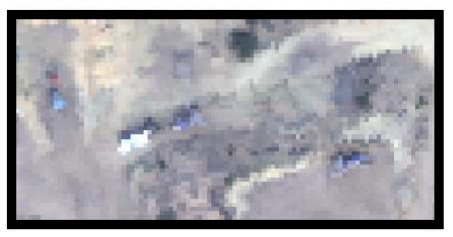

(d) Google Earth: 15 March 2015

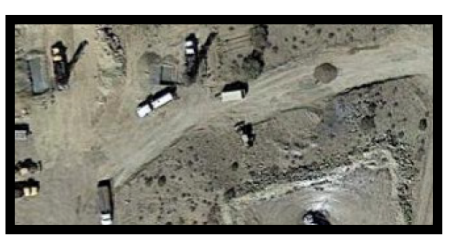

(b) $\mathrm{CH}_{4}$ : 20 April 2015, 18:06:24 UTC

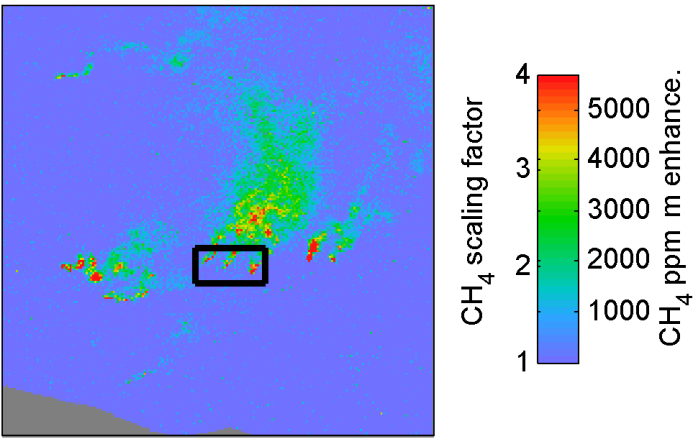

(e) $\mathrm{H}_{2} \mathrm{O}: 20$ April 2015, 18:06:24 UTC

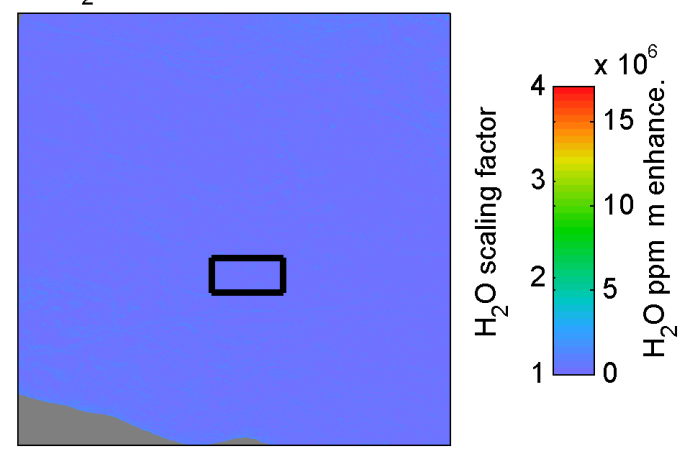

Figure 3. (a) AVIRIS-NG true color image subset. (b) A number of $\mathrm{CH}_{4}$ plumes are clearly visible with maximum enhancements in excess of $5000 \mathrm{ppm} \cdot \mathrm{m}$. (c) Close-up of AVIRIS-NG true color image shown by black outline in (a). (d) Higher-resolution Google Earth imagery for same area reveals drilling rigs at an active underground coal mine, suggesting that the origin of these plumes is mine workings ventilation shafts. (e) $\mathrm{H}_{2} \mathrm{O}$ retrieval does not indicate enhancements. For all images, north is up.

In a previous study (Thorpe et al., 2014), the iterative maximum a posteriori differential optical absorption spectroscopy (IMAP-DOAS) retrieval was applied to AVIRIS for quantitative mapping of $\mathrm{CH}_{4}$ from natural and anthropogenic sources. In this study, the application of IMAP-DOAS has been expanded for use with AVIRIS-NG for multiple gas species, including $\mathrm{CH}_{4}, \mathrm{CO}_{2}$, and $\mathrm{H}_{2} \mathrm{O}$. We present results from AVIRIS-NG data acquired in New Mexico and Colorado, including from a flight campaign in the San Juan Basin near Four Corners. We will present results for a number of sources, including $\mathrm{CH}_{4}$ from mine ventilation shafts, a gas processing plant, tank, pipeline leak, and natural seep, as well as $\mathrm{CO}_{2}$ and $\mathrm{H}_{2} \mathrm{O}$ plumes associated with power plants (Fig. 2).

\section{Study sites and AVIRIS-NG data}

Space-based observations collected by the SCanning Imaging Absorption SpectroMeter for Atmospheric CHartographY (SCIAMACHY) instrument (Bovensmann et al., 1999) showed $\mathrm{CH}_{4}$ enhancements in the Four Corners region (Kort et al., 2014). This made for an ideal location for follow-up

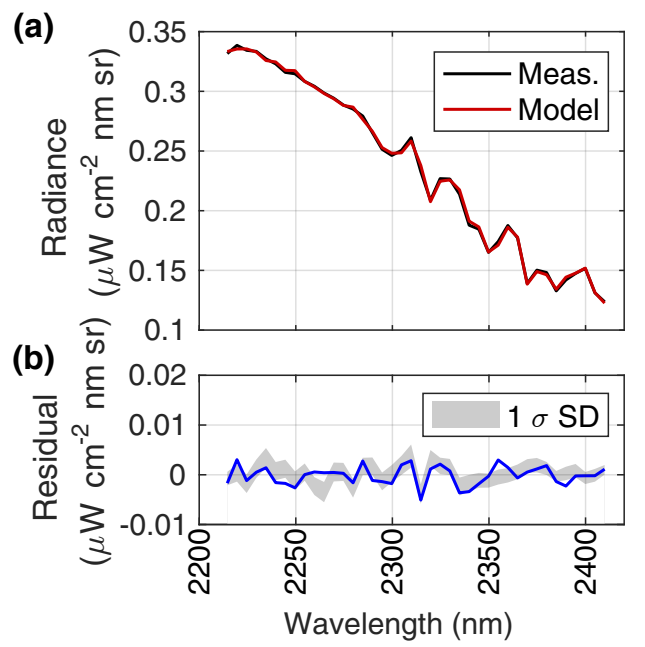

Figure 4. (a) AVIRIS-NG measured and modeled radiance for one image pixel within the $\mathrm{CH}_{4}$ plume used for the $\mathrm{CH}_{4}$ retrieval (see Fig. 3b). (b) The residual is plotted with $1 \sigma$ SD boundary calculated from residuals for the entire scene. 


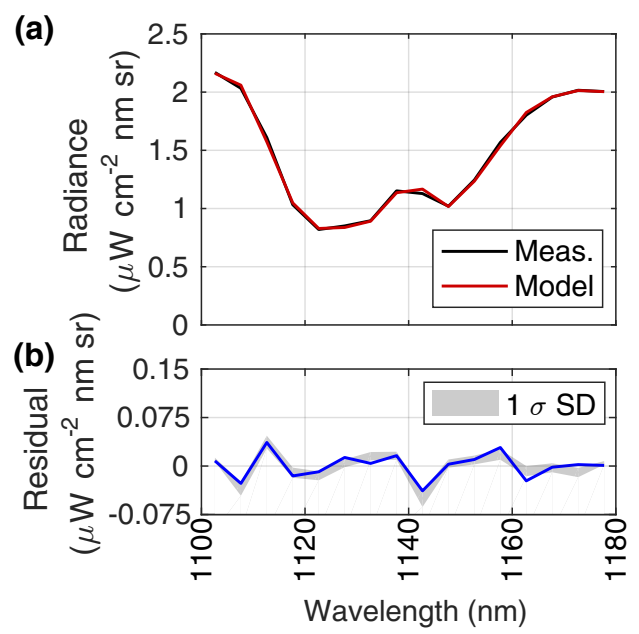

Figure 5. (a) AVIRIS-NG measured and modeled radiance for one image pixel within the $\mathrm{CH}_{4}$ plume used for the $\mathrm{H}_{2} \mathrm{O}$ retrieval (see Fig. 3e). (b) The residual is plotted with $1 \sigma$ SD boundary calculated from residuals for the entire scene.

surveys using AVIRIS-NG to identify individual emission sources. During the flight campaign, the AVIRIS-NG instrument was equipped with a real-time $\mathrm{CH}_{4}$ mapping capability using a waterfall display monitored by the instrument operator. Observed $\mathrm{CH}_{4}$ plumes were overlaid on a true color image displaying location information and the maximum $\mathrm{CH}_{4}$ enhancement (Thompson et al., 2015b). This permitted adaptive survey strategies to investigate observed plumes and the ability to send images of the plume with accurate locations to a ground crew for subsequent follow-up. A Xenics Onca-VLWIR-MCT-384 thermal imaging camera with a Spectrogon optical filter centered at $7.746 \mu \mathrm{m}$ was used by the ground crew to verify a number of plumes observed in real time by AVIRIS-NG.

Located in New Mexico and Colorado, the San Juan Basin produces natural gas from sandstone, coal bed $\mathrm{CH}_{4}$, and shale formations and is the fourth largest US gas field when it comes to total production (EIA, 2015). During a 5-day campaign in April 2015, AVIRIS-NG targeted an area corresponding to the highest $\mathrm{CH}_{4}$ enhancements observed with SCIAMACHY (Frankenberg et al., 2016). A $2500 \mathrm{~km}^{2}$ area was covered in approximately 2 days (9.2 flight hours) flying at $3 \mathrm{~km}$ a.g.l., resulting in scenes with an image swath of around $1.8 \mathrm{~km}$ and a ground resolution of $3 \mathrm{~m}$. The remaining flight days were used for additional follow-up flights and some repeat observations, sometimes at lower flight altitudes. During the campaign, a number of potential $\mathrm{CH}_{4}$ emission sources were targeted, including infrastructure associated with natural gas production like well pads, tanks, gas processing plants, a coal mine, and natural coal bed $\mathrm{CH}_{4}$ seeps. While the flight campaign focused on $\mathrm{CH}_{4}$ sources, the coal-fired San Juan power-generating station was also flown as a potential $\mathrm{CO}_{2}$ emission source.

\section{IMAP-DOAS retrievals}

A detailed description of the IMAP-DOAS retrieval for AVIRIS can be found in Thorpe et al. (2014). Gas retrievals were performed on orthocorrected radiance data. Atmospheric profiles were generated by updating prior gas profiles from the US standard atmosphere obtained from the radiative transfer models LOWTRAN/MODTRAN (Kneizys et al., 1996) using volume mixing ratios (VMRs) from the NOAA Mauna Loa station, United States (NOAA, 2015). Temperature, pressure, and water vapor VMR profiles representative of the time period of the flight campaign were acquired from the National Centers for Environmental Prediction/National Center for Atmospheric Research (NCEP/NCAR) reanalysis project (Kalnay et al., 1996). Spectral parameters for $\mathrm{CH}_{4}$, $\mathrm{CO}_{2}, \mathrm{H}_{2} \mathrm{O}$, and $\mathrm{N}_{2} \mathrm{O}$ were used from the HITRAN 2008 database (Rothman et al., 2009) and a classical Voigt spectral line shape was used to calculate vertical optical densities for 14 atmospheric layers that spanned sea level to the top of the atmosphere.

Above the aircraft, vertical optical densities were combined and an air mass factor (AMF) was calculated to account for one-way transmission. Vertical optical densities below the aircraft were also combined with an AMF reflecting two-way transmission. This resulted in a two-layer atmospheric model that speeds up the retrieval and incorporates the ground elevation and flight altitude for each AVIRIS-NG scene. The two-layer model was used to model reflected solar radiation perturbed by the absorbing species $\mathrm{CH}_{4}, \mathrm{CO}_{2}$, $\mathrm{H}_{2} \mathrm{O}$, and $\mathrm{N}_{2} \mathrm{O}$. Three retrieval windows were used, each targeting the primary gas of interest. $\mathrm{CH}_{4}$ retrievals were performed between 2215 and $2410 \mathrm{~nm}$ (Fig. 1) and included fits for $\mathrm{H}_{2} \mathrm{O}$ and $\mathrm{N}_{2} \mathrm{O}$. Gas Jacobians that reflect changes in absorption due to the absorbing species $\mathrm{CH}_{4}, \mathrm{CO}_{2}$, and $\mathrm{H}_{2} \mathrm{O}$ are shown in Fig. 1. Because $\mathrm{N}_{2} \mathrm{O}$ has weak absorption features, these Jacobians are not shown. Between 1904 and $2099 \mathrm{~nm}, \mathrm{CO}_{2}$ retrievals included $\mathrm{H}_{2} \mathrm{O}$ and $\mathrm{N}_{2} \mathrm{O}$ as additional unknown variables of the retrieval, while $\mathrm{H}_{2} \mathrm{O}$ retrievals between 1103 and $1178 \mathrm{~nm}$ also included $\mathrm{CO}_{2}$ and $\mathrm{N}_{2} \mathrm{O}$. Therefore, the state vector $\left(\boldsymbol{x}_{n}\right)$ for each retrieval window has six entries (three gases for two atmospheric layers). Modeled radiance at high spectral resolution was calculated for each wavelength with a forward radiative transfer model using the following equation:

$$
\boldsymbol{F}^{\mathrm{hr}}\left(\boldsymbol{x}_{i}\right)=\boldsymbol{I}_{0}^{\mathrm{hr}} \cdot \exp \left(-\sum_{n=1}^{6} \boldsymbol{A}_{n} \cdot \boldsymbol{\tau}_{n}^{\mathrm{ref}} \cdot \boldsymbol{x}_{n, i}\right) \cdot \sum_{i=0}^{k} a_{k} \lambda^{k},
$$

where $\boldsymbol{F}^{\mathrm{hr}}\left(\boldsymbol{x}_{i}\right)$ is the forward modeled radiance at the $i$ th iteration of the state vector; $\boldsymbol{I}_{0}^{\mathrm{hr}}$ is the incident intensity, a solar transmission spectrum (G. Toon, personal communication, 2013); $\boldsymbol{A}_{n}$ is the AMF for each $n$ number of atmospheric state vector elements; $\boldsymbol{\tau}_{n}^{\text {ref }}$ is the reference vertical optical density for each $n$ number of atmospheric state vector elements (including optical densities of the three absorbing species); $\boldsymbol{x}_{n, i}$ 
is the trace-gas-related state vector at the $i$ th iteration, which scales the prior optical densities of each of the absorbing species in each $n$ layer (six rows, three gases for two atmospheric layers); and $a_{k}$ are polynomial coefficients to account for low-frequency spectral variations.

The state vector contains the spectral shift (not shown here) and a low-order polynomial function $\left(a_{k}\right)$ to account for the broadband variability in surface albedo (see Frankenberg et al., 2005). The high-resolution modeled radiance is convolved using the instrument line shape function and sampled to the center wavelengths for each AVIRIS-NG spectral band, resulting in a lower-resolution modeled radiance at the $i$ th iteration of the state vector $\boldsymbol{F}^{\mathrm{lr}}\left(\boldsymbol{x}_{i}\right)$, calculated using a known $\boldsymbol{\tau}_{n}^{\text {ref }}$ scaled by $\boldsymbol{x}_{n, i}$.

A Jacobian matrix is calculated for each iteration $i$, where each column represents the derivate vector of the sensor radiance with respect to each element of the state vector $\left(\boldsymbol{x}_{i}\right)$.

$\mathbf{K}_{i}=\left.\frac{\partial \boldsymbol{F}^{\operatorname{lr}}(\boldsymbol{x})}{\partial \boldsymbol{x}}\right|_{\boldsymbol{x}_{i}}$

The state vector at the $i$ th iteration can be optimized as follows (Rodgers, 2000):

$$
\begin{aligned}
& \boldsymbol{x}_{i+1}= \boldsymbol{x}_{\mathrm{a}}+\left(\mathbf{K}_{i}^{T} \mathbf{S}_{\varepsilon}^{-1} \mathbf{K}_{i}+\mathbf{S}_{\mathrm{a}}^{-1}\right)^{-1} \mathbf{K}_{i}^{T} \mathbf{S}_{\varepsilon}^{-1} \\
& \cdot\left[\boldsymbol{y}-\boldsymbol{F}^{\operatorname{lr}}\left(\boldsymbol{x}_{i}\right)+\mathbf{K}_{i}\left(\boldsymbol{x}_{i}-\boldsymbol{x}_{\mathrm{a}}\right)\right],
\end{aligned}
$$

where $\boldsymbol{x}_{\mathrm{a}}$ is the a priori state vector (six rows), $\boldsymbol{x}_{i}$ is the state vector at the $i$ th iteration (six rows), $\mathbf{S}_{\varepsilon}$ is the error covariance matrix, $\mathbf{S}_{\mathrm{a}}$ is the a priori covariance matrix, $\boldsymbol{y}$ is the measured AVIRIS-NG radiance, $\boldsymbol{F}^{\mathrm{lr}}\left(\boldsymbol{x}_{i}\right)$ is the forward model evaluated at $\boldsymbol{x}_{i}$, and $\mathbf{K}_{i}$ is the Jacobian of the forward model at $\boldsymbol{x}_{i}$.

The retrieval optimizes a scaling factor relative to the a priori profile. The a priori scaling factor is set to one as an initial guess for each gas in the two layers, while the a priori covariance matrix was set to constrain the fit to the atmospheric layer beneath the aircraft where high variance is expected. To do so, very small prior covariances were set for the uppermost layer (above the aircraft). Because the observed plumes are not expected to extend above the AVIRIS-NG flight altitude, this assumption is reasonable. Gas concentrations were calculated in $\mathrm{ppm} \cdot \mathrm{m}$ by multiplying the gas state vector at the last iteration (gas scaling factor) by the VMR for the lowest layer of the reference atmosphere and the distance between the aircraft and the ground. In subsequent figures, color bars will indicate the scaling factors and gas enhancements relative to background, which were calculated by subtracting the retrieved gas concentration from the background concentration for the lowest layer of the reference atmosphere.

The covariance $\hat{S}$ was calculated to estimate expected IMAP-DOAS retrieval errors as follows:

$\hat{S}=\left(\mathbf{K}^{T} \mathbf{S}_{\varepsilon}^{-1} \mathbf{K}+\mathbf{S}_{\mathrm{a}}^{-1}\right)^{-1}$, where the diagonal of $\hat{S}$ corresponds to the covariance at each atmospheric layer associated with the gases used for each fitting window. $\mathbf{S}_{\varepsilon}$, the error covariance matrix, is a diagonal matrix representing expected errors for the retrieval algorithm. For each gas retrieval, the square root of the corresponding diagonal entry of $\hat{S}$ is multiplied by the VMR in the lowest layer of the atmospheric model for each retrieved gas $\left(\mathrm{CH}_{4}: 1.86 \mathrm{ppm} ; \mathrm{CO}_{2}: 399 \mathrm{ppm} ; \mathrm{H}_{2} \mathrm{O}: 7745 \mathrm{ppm}\right)$. Using scene parameters for a $1 \mathrm{~km}$ flight altitude a.g.l. with $25.6^{\circ}$ solar zenith and variable signal-to-noise ratio, this corresponds to an error of between 0.14 and $0.55 \mathrm{ppm} \mathrm{CH}_{4}$ beneath the aircraft. For $\mathrm{CO}_{2}$, the error ranges between 6.6 and $26.4 \mathrm{ppm}$ and for $\mathrm{H}_{2} \mathrm{O}$ between 9.4 and $37.5 \mathrm{ppm}$.

\section{Results}

\section{$5.1 \mathrm{CH}_{4}$ emissions from natural gas sector}

AVIRIS-NG identified over $250 \mathrm{CH}_{4}$ plumes during the Four Corners flight campaign (Frankenberg et al., 2016) using a linearized matched filter (Thompson et al., 2015b). The linearized matched filter models the background of radiance spectra as a multivariate Gaussian and provides a scalar value that represents the fraction of the gas target signature that perturbs the background. Because the target signature is defined as the change in radiance of the background caused by adding a unit mixing ratio length of $\mathrm{CH}_{4}$, detected quantities are reported in mixing ratio lengths $(\mathrm{ppm} \cdot \mathrm{m})$. This method is computationally efficient and accounts for the full covariance of background (atmosphere and surface) and instrument noise using in-scene data, providing high sensitivity to local enhancements.

The current speed of the IMAP-DOAS retrieval algorithm precludes it from being applied to all 250 examples presented in the previous study (Frankenberg et al., 2016). Instead, IMAP-DOAS retrievals for only a few examples will be presented here, reflecting $\mathrm{CH}_{4}, \mathrm{CO}_{2}$, and $\mathrm{H}_{2} \mathrm{O}$ plumes from a variety of emission sources. The first example from a 20 April 2015 flight at $1.1 \mathrm{~km}$ a.g.l. (Fig. 3b) is made up of at least 10 plumes with maximum enhancements in excess of $5000 \mathrm{ppm} \mathrm{m}$, which is equivalent to a concentration of $0.5 \%$ in a $1 \mathrm{~m}$ thick layer or roughly an $\mathrm{XCH}_{4}$ (dry air columnaveraged mole fraction) enhancement of around $500 \mathrm{ppb}$ that is almost $25 \%$ of a total background column. Results from the $\mathrm{H}_{2} \mathrm{O}$ retrieval (Fig. 3e) do not indicate enhancements collocated with $\mathrm{CH}_{4}$ plumes. The true color image subset in Fig. 3a reveals a few dirt roads, but the close-up of the AVIRIS-NG scene indicated by the black boxes in Fig. 3a and $b$ indicates some visible infrastructure that is difficult to interpret at the $1 \mathrm{~m}$ AVIRIS-NG pixel resolution (Fig. 3c).

In Fig. 3d, Google Earth imagery for the same area provides improved spatial resolution and reveals what appears to be drilling rigs at an active underground coal mine on 15 March 2015, suggesting the origin of these plumes are mine 
(a) 23 Apr $2015,18: 34: 18$ UTC

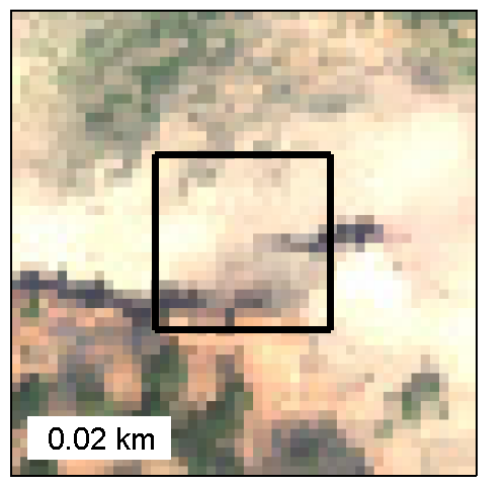

(c) 23 Apr $2015,18: 34: 18$ UTC

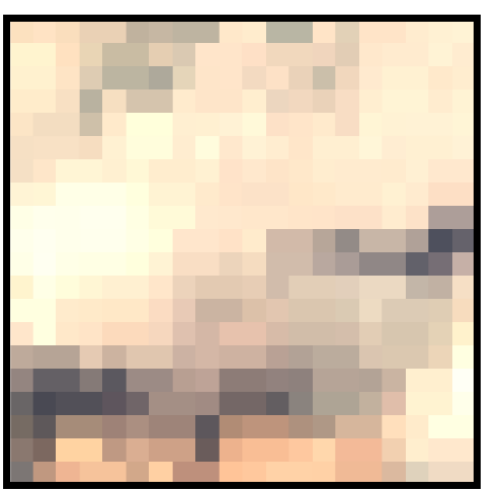

(b) $\mathrm{CH}_{4}: 23$ Apr $2015,18: 34: 18$ UTC

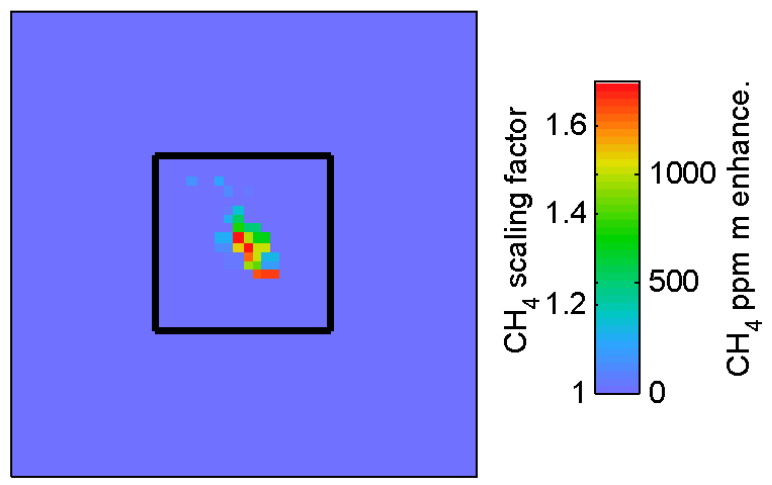

(d) Google Earth: 11 Aug 2015

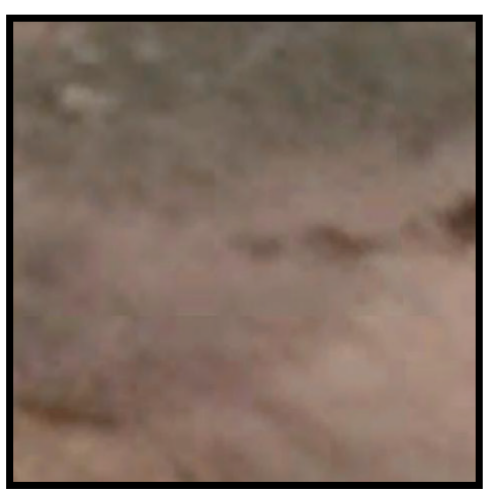

Figure 6. (a) AVIRIS-NG true color image subset. (b) A small $\mathrm{CH}_{4}$ plume is visible from a confirmed geological source at Moving Mountain near Durango, Colorado. (c) Close-up of AVIRIS-NG true color image. (d) Higher-resolution Google Earth imagery provides additional spatial context. For all images, north is up.

workings ventilation shafts. Frankenberg et al. (2016) estimated an aggregate flux of $2236 \mathrm{kgh}^{-1}$ for these plumes. Measured and modeled radiance is shown for one image pixel within the $\mathrm{CH}_{4}$ plume for the $\mathrm{CH}_{4}$ retrieval fitting window (Fig. 4a) and for the $\mathrm{H}_{2} \mathrm{O}$ retrieval (Fig. 5a). For both examples, the residuals are also plotted (Fig. 4b, Fig. 5b) in addition to the $1 \sigma$ SD boundary calculated from residuals for the entire scene.

Additional examples are presented in Appendix A, including from another 20 April 2015 flight at $1.4 \mathrm{kma.g} .1$. that results in a $1.2 \mathrm{~m}$ resolution (Fig. A1b). Multiple $\mathrm{CH}_{4}$ plumes are visible from this gas processing facility, one emanating from a source beyond the east edge of the AVIRIS-NG scene. This example was associated with a planned maintenance operation, which resulted in a large temporary $\mathrm{CH}_{4}$ plume that was recorded and reported through the normal Greenhouse Gas Reporting Program (Williams, 2016). A second plume is visible at a location shown by the black box in Fig. A1a, indicating white pipes associated with an interstate pipeline as the likely emission source (Fig. A1c and d).

An $\mathrm{H}_{2} \mathrm{O}$ retrieval was also performed for this scene and did not reveal enhancements collocated with the $\mathrm{CH}_{4}$ plumes. For all subsequent examples, $\mathrm{H}_{2} \mathrm{O}$ retrievals were performed but will be shown only in cases where $\mathrm{H}_{2} \mathrm{O}$ plumes were observed (see Sect. 5.3). As shown in Fig. A1a, the $\mathrm{CH}_{4}$ plumes cross over many land cover types with variable brightness and very dark surfaces resulted in anomalously high retrievals. $\mathrm{CH}_{4}$ results from radiances less than $0.01 \mu \mathrm{W} \mathrm{cm}{ }^{-2} \mathrm{sr}^{-1} \mathrm{~nm}^{-1}$ for any band of the $\mathrm{CH}_{4}$ fitting window, corresponding to shadows and water, were removed from the results shown in Fig. A1b.

In Fig. A2b and e, $\mathrm{CH}_{4}$ emissions from a tank were observed on 19 and 21 April 2015 at 2.8 and $3.2 \mathrm{~km}$ a.g.l. (pixel resolutions of 2.6 and $3.0 \mathrm{~m}$ respectively). The Google Earth close-up shown in Fig. A2d indicates a tank as the likely emission source, which was confirmed by the ground crew using a thermal imaging camera on multiple days. Video A1 (see Supplement) was acquired on 21 April 2015 at around 18:00 UTC and clearly shows a $\mathrm{CH}_{4}$ plume originating at the top of the tank that is consistent with the AVIRIS-NG $\mathrm{CH}_{4}$ plume observed the same day.

In Frankenberg et al. (2016), $\mathrm{CH}_{4}$ emissions from a pipeline leak were presented (see Fig. 4 and Movie S2; Frankenberg et al., 2016) and subsequent to publication another suspected pipeline leak (Fig. S6; Frankenberg et al., 2016) was confirmed (K. Spray, Department of Energy, per- 
(a) 20 April 2015, 18:13:45 UTC

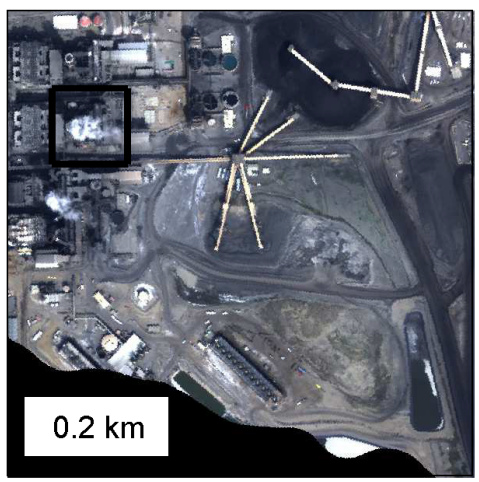

(c) 20 April 2015, 18:13:45 UTC

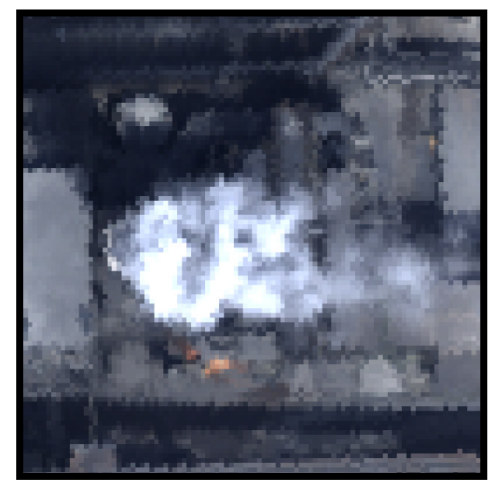

(b) $\mathrm{CO}_{2}: 20$ April $2015,18: 13: 45$ UTC

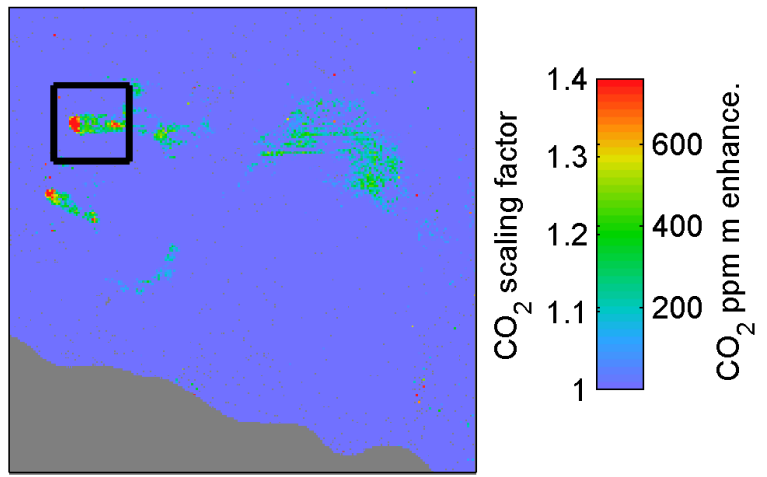

(d) Google Earth: 15 March 2015

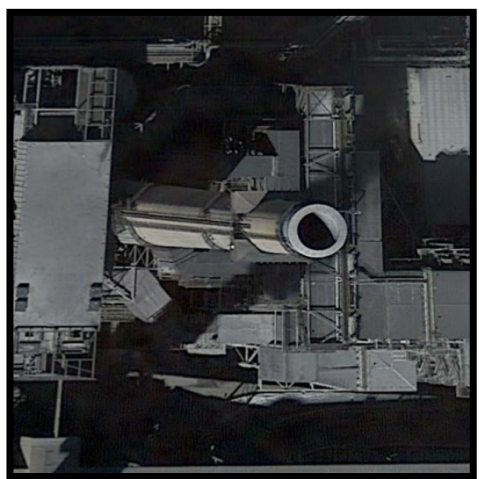

Figure 7. (a) AVIRIS-NG true color image subset. (b) $\mathrm{CO}_{2}$ plume is visible. (c) Close-up of AVIRIS-NG true color image. (d) Higherresolution Google Earth imagery provides additional spatial context. For all images, north is up.

(a)

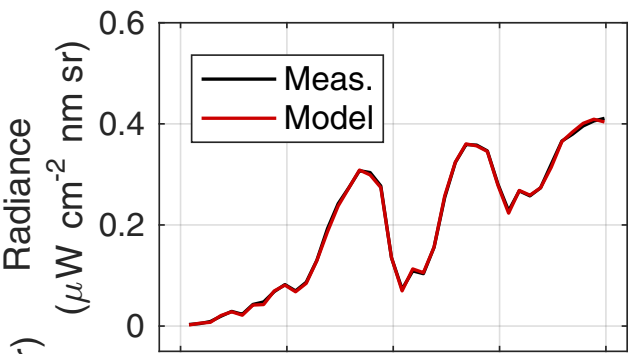

(b) $\overparen{\bar{c}}$

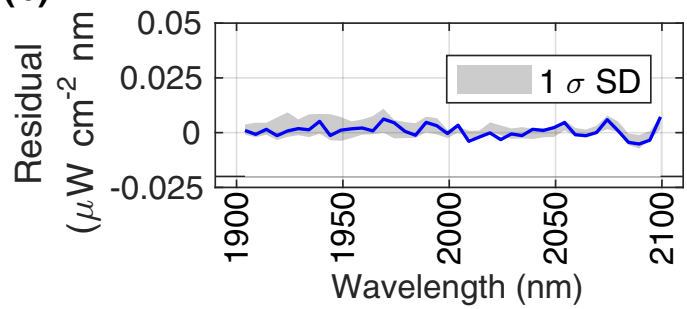

Figure 8. (a) AVIRIS-NG measured and modeled radiance for one image pixel within the $\mathrm{CO}_{2}$ plume for the $\mathrm{CO}_{2}$ retrieval (see Fig. 7b). (b) The residual is plotted with $1 \sigma$ SD boundary calculated from residuals for the entire scene. sonal communication, 2016). That leak was independently identified and repaired by the operator as a part of their normal operations prior to publication. In Fig. A3b, the $\mathrm{CH}_{4}$ plume from the 19 April 2015 flight at $3.0 \mathrm{kma.g} .1$. $(2.7 \mathrm{~m}$ pixel resolution) does not appear associated with visible infrastructure and subsequent investigation by the ground crews identified the plume origin on 24 April 2015 using the thermal camera (Video A2, see Supplement). This location was along a marked, buried natural gas pipeline and was subsequently confirmed as a pipeline leak and ultimately shut down for repairs by the local pipeline operators. The estimated flux for this example is $28 \mathrm{~kg} \mathrm{~h}^{-1}$ (Frankenberg et al., 2016), which would result in an estimated annual loss of 13.2 million cubic feet, equivalent to USD 100000 (assuming constant annual flux and average cost of USD 7.40 per thousand cubic feet).

\subsection{Geological $\mathrm{CH}_{4}$ emissions}

AVIRIS has been used for quantitative retrievals of $\mathrm{CH}_{4}$ for marine seeps (Roberts et al., 2010; Thorpe et al., 2014) and more recently a plume observed with AVIRIS-NG was verified as a geological source (see Fig. S6 in Frankenberg et al., 2016). Subsequent analysis of the Four Corners data set revealed another $\mathrm{CH}_{4}$ plume from a confirmed geological 
source at Moving Mountain near Durango, Colorado (LTE, 2015). This AVIRIS-NG scene was acquired at $1.3 \mathrm{~km}$ a.g.1. ( $1 \mathrm{~m}$ pixel resolution) and shows a $10 \mathrm{~m}$ long plume (Fig. 6b).

\section{3 $\mathrm{CO}_{2}$ and $\mathrm{H}_{2} \mathrm{O}$ emissions from power plants}

While Dennison et al. (2013) demonstrated the ability of AVIRIS for high-resolution mapping of $\mathrm{CO}_{2}$ plumes, in this study we present two examples using quantitative retrievals. The first example is from the coal-fired San Juan Generating Station near Farmington, New Mexico, that was flown on 20 April 2015 at $1.2 \mathrm{~km}$ a.g.l. Two $\mathrm{CO}_{2}$ plumes are clearly visible in Fig. 7b and correspond to two flue-gas stacks that appear active given visible emissions in the true color image (Fig. 7a, c). A third flue-gas stack appears inactive (Fig. 7a) with no visible $\mathrm{CO}_{2}$ plume (Fig. 7b). The San Juan Generating Station reported 2015 emissions of $9843 \mathrm{kt}$ of $\mathrm{CO}_{2}$, equivalent to a flux of $1123666 \mathrm{~kg} \mathrm{CO}_{2} \mathrm{~h}^{-1}$ (EPA, 2016b). An example of a $\mathrm{CO}_{2}$ retrieval fit and the residual is shown in (Fig. 8).

The second example is from a 12 September 2014 flight that included the coal-fired Craig Station near Craig, Colorado. $\mathrm{CO}_{2}$ plumes are visible from flue-gas stacks (Fig. A4b) and extend more than $1 \mathrm{~km}$ downwind. This power plant reported 2014 emissions of $9300 \mathrm{kt}$ of $\mathrm{CO}_{2}$, equivalent to a flux of $1061644 \mathrm{kgCO}_{2} \mathrm{~h}^{-1}$ (EPA, 2016b). Within the same scene, an $\mathrm{H}_{2} \mathrm{O}$ plume is also visible (Fig. A4d) emanating from a region that contains a number of cooling towers adjacent to two large cooling ponds (Fig. A5a). $\mathrm{CH}_{4}$ retrieval results are also shown in Fig. A5c, indicating that $\mathrm{CH}_{4}$ plumes are not visible in the scene and emphasizing the ability of these retrievals to distinguish between $\mathrm{CH}_{4}$ and $\mathrm{H}_{2} \mathrm{O}$ despite spectral interference (see Fig. 1). Results for dark surfaces like the cooling ponds were removed from Fig. A4b by excluding radiances less than $0.10 \mu \mathrm{W} \mathrm{cm}{ }^{-2} \mathrm{sr}^{-1} \mathrm{~nm}^{-1}$ for any band of the $\mathrm{CO}_{2}$ fitting window, for radiances less than $0.002 \mu \mathrm{W} \mathrm{cm}{ }^{-2} \mathrm{sr}^{-1} \mathrm{~nm}^{-1}$ for any band of the $\mathrm{H}_{2} \mathrm{O}$ fitting window (Fig. A4d), and for radiances less than $0.01 \mu \mathrm{W} \mathrm{cm}{ }^{-2} \mathrm{sr}^{-1} \mathrm{~nm}^{-1}$ for any band of the $\mathrm{CH}_{4}$ fitting window (Fig. A4c).

In Fig. A5a, the AVIRIS-NG true color image is shown for the close-up indicated by the black box in Fig. A4. The flue-gas stacks are visible in the lower left as $\mathrm{CO}_{2}$ sources and cooling towers in the upper right as possible $\mathrm{H}_{2} \mathrm{O}$ sources. Ellipses delineate the shapes of plumes visible in the true color images for the flue-gas stacks (red) and cooling towers (blue). The arrows indicate winds to the southeast for the flue-gas stacks (consistent with $\mathrm{CO}_{2}$ plumes in Fig. A4b) and to the east for the cooling towers (consistent with $\mathrm{H}_{2} \mathrm{O}$ plumes in Fig. A4d). In A5b, the higher-resolution Google Earth imagery clearly indicates the flue-gas stacks are much taller (182 m) than the cooling tower (TRI, 2016) based on assessment of shadows, which could explain variable wind directions at the flue-gas stacks and in the vicinity of the cooling towers. Given the presence of the cooling ponds immediately adjacent to the cooling towers, it is unclear whether the observed $\mathrm{H}_{2} \mathrm{O}$ plume shown in Fig. A4d is caused solely by the cooling towers or reflects the combined influence of the towers and evaporation from the cooling ponds.

\section{Conclusions}

In this study, we use the airborne imaging spectrometer AVIRIS-NG and the IMAP-DOAS retrieval to generate gas concentration maps for observed $\mathrm{CH}_{4}, \mathrm{CO}_{2}$, and $\mathrm{H}_{2} \mathrm{O}$ plumes. While more than $250 \mathrm{CH}_{4}$ plumes were observed in the San Juan Basin near Four Corners (Frankenberg et al., 2016), this study focused on a few results from anthropogenic and natural sources, including emissions from mine ventilation shafts, a gas processing plant, tank, pipeline leak, and natural seep. In addition, $\mathrm{CO}_{2}$ emissions were observed from the flue stacks of two coal-fired power plants and an $\mathrm{H}_{2} \mathrm{O}$ plume was mapped for the cooling towers for one power plant. Observed plumes were consistent with known and suspected emission sources verified by true color AVIRIS-NG imagery and higher-resolution Google Earth imagery.

AVIRIS-NG has the high spatial resolution necessary to resolve small-scale emissions and can map large regions quickly, covering the $2500 \mathrm{~km}^{2}$ Four Corners study in approximately 2 days (9.2 flight hours). This capability is aided by real-time detection and geolocation of gas plumes, permitting unambiguous identification of individual emission source locations and communication to ground teams for rapid follow-up. This permitted verification of a number of emission sources presented in this study using a thermal camera, including a tank and buried natural gas pipeline. The AVIRIS and AVIRIS-NG instruments have demonstrated $\mathrm{CH}_{4}$ plume mapping capabilities at multiple flight altitudes, ranging from as low as 0.4 to $3.8 \mathrm{~km}$ a.g.l. $(0.4$ to $3.8 \mathrm{~m}$ pixels) for a controlled release experiment (Thorpe et al., 2016a) to $9 \mathrm{kma.g.l}$. for the Coal Oil Point marine seeps (Thorpe et al., 2014). AVIRIS observed the Aliso Canyon leak on multiple flight days at $6.6 \mathrm{kma}$.g.1. $(6.6 \mathrm{~m}$ pixels) while the Hyperion imaging spectrometer, also $10 \mathrm{~nm}$ spectral resolution but $30 \mathrm{~m}$ pixels, mapped the plume and demonstrated the potential for a space-based application (Thompson et al., 2016).

This study demonstrates a comprehensive greenhouse gas monitoring capability that targets $\mathrm{CH}_{4}$ and $\mathrm{CO}_{2}$, the two dominant anthropogenic climate-forcing agents. The ability to identify individual point source locations of $\mathrm{CH}_{4}$ and $\mathrm{CO}_{2}$ emissions has relevance to the research community and the private sector. Understanding the spatial and temporal distribution and the magnitude of these emissions is of interest given the large uncertainties associated with anthropogenic emissions. This includes industrial point source emissions of $\mathrm{CH}_{4}$ and $\mathrm{CO}_{2}, \mathrm{CH}_{4}$ from oil and gas operations as well as natural gas distribution and storage, $\mathrm{CH}_{4}$ from agricul- 
tural sources, and $\mathrm{CH}_{4}$ and $\mathrm{CO}_{2}$ from landfills. Site operators could identify and mitigate $\mathrm{CH}_{4}$ emissions, which reflect both a potential safety hazard and lost revenue. Water vapor results demonstrate the ability of these retrievals to distinguish between $\mathrm{CH}_{4}$ and $\mathrm{H}_{2} \mathrm{O}$ despite spectral interference in the shortwave infrared while offering the potential to improve atmospheric correction and reflectance retrievals with application to the fields of ecology and meteorology.

Despite these promising results, an imaging spectrometer built exclusively for quantitative mapping of gas plumes would have improved sensitivity compared to AVIRIS-NG (Thorpe et al., 2014). For example, an instrument providing a $1 \mathrm{~nm}$ spectral resolution and sampling (2000-2400 nm) would permit mapping $\mathrm{CH}_{4}, \mathrm{CO}_{2}, \mathrm{H}_{2} \mathrm{O}, \mathrm{CO}$, and $\mathrm{N}_{2} \mathrm{O}$ from more diffuse sources using both airborne and orbital platforms (Thorpe et al., 2016b). The ability to identify emission sources offers the potential to constrain regional greenhouse gas budgets and improve partitioning between anthropogenic and natural emission sources. Because the $\mathrm{CH}_{4}$ lifetime is only about 9 years and $\mathrm{CH}_{4}$ has a high GWP, targeting reductions in anthropogenic $\mathrm{CH}_{4}$ emissions offers an effective approach to decrease overall atmospheric radiative forcing.

Data availability. The AVIRIS-NG data used in this study are available upon request at http://avirisng.jpl.nasa.gov/ or http://aviris.jpl.nasa.gov/. Videos showing methane plumes observed using a thermal imaging camera are available at https://doi.org/10.5446/30884 and https://doi.org/10.5446/30883 (Thorpe and Krohn, 2017a, b). 


\section{Appendix A}

This appendix contains additional figures referenced in Sect. 5.

\section{A1 $\mathrm{CH}_{4}$ emissions from gas processing facility}

(a) 20 April 2015, 16:07:19 UTC

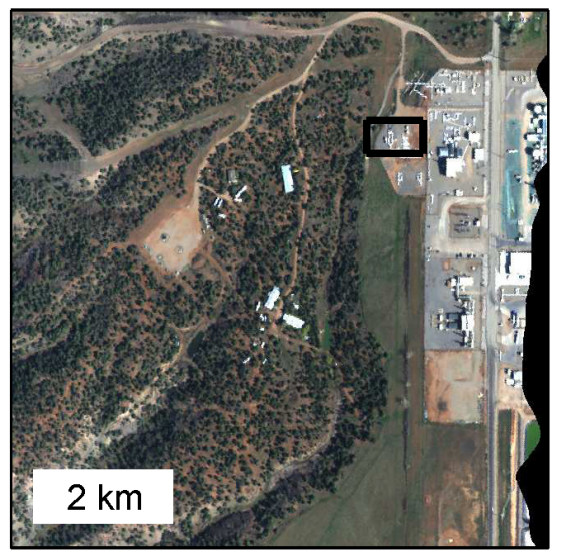

(c) 20 April 2015, 16:07:19 UTC

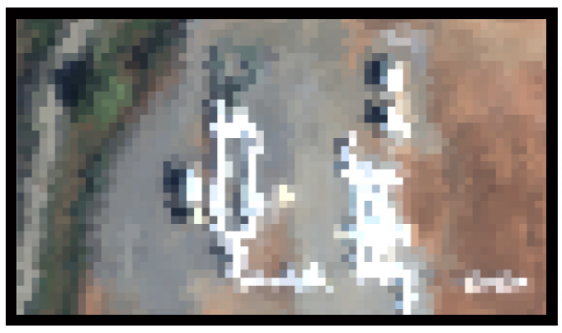

(b) $\mathrm{CH}_{4}: 20$ April 2015, 16:07:19 UTC

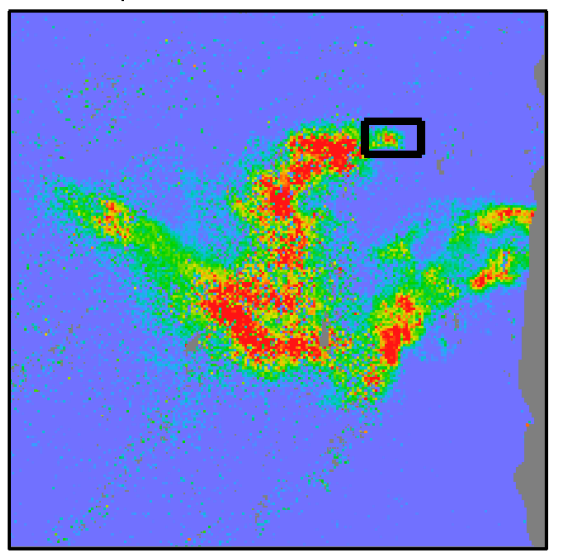

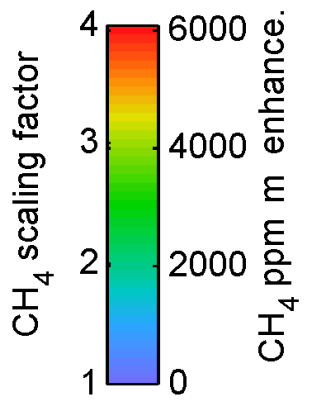

(d) Google Earth: 16 March 2015

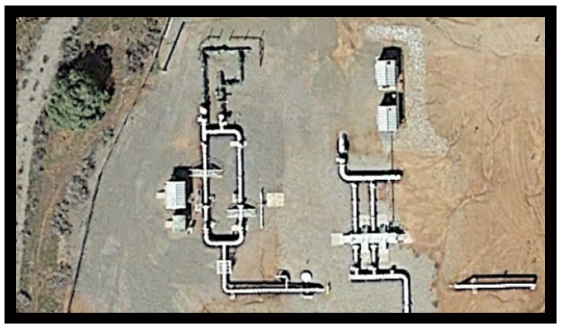

Figure A1. (a) AVIRIS-NG true color image subset. (b) Multiple $\mathrm{CH}_{4}$ plumes are visible from this gas processing facility, one emanating from a source beyond the east edge of the AVIRIS-NG scene. A second plume is visible at a location shown by the black box. (c) Close-up of AVIRIS-NG true color image indicates white pipes associated with an interstate pipeline as the likely emission source. (d) Higher-resolution Google Earth imagery provides additional spatial context. For all images, north is up. 


\section{A2 $\mathrm{CH}_{4}$ emissions from tank}

(a) 19 April 2015, 22:11:27 UTC

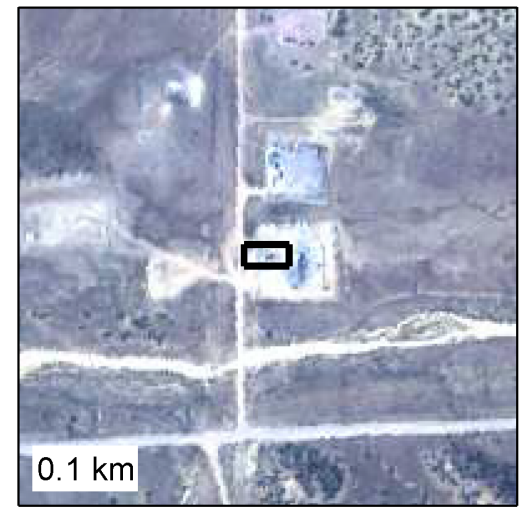

(c) 19 April 2015, 22:11:27 UTC

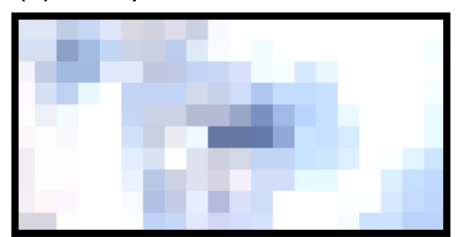

(d) Google Earth: 15 March 2015

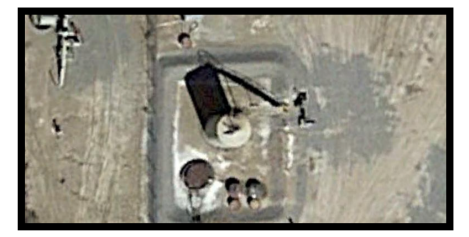

(b) $\mathrm{CH}_{4}: 19$ April 2015, 22:11:27 UTC

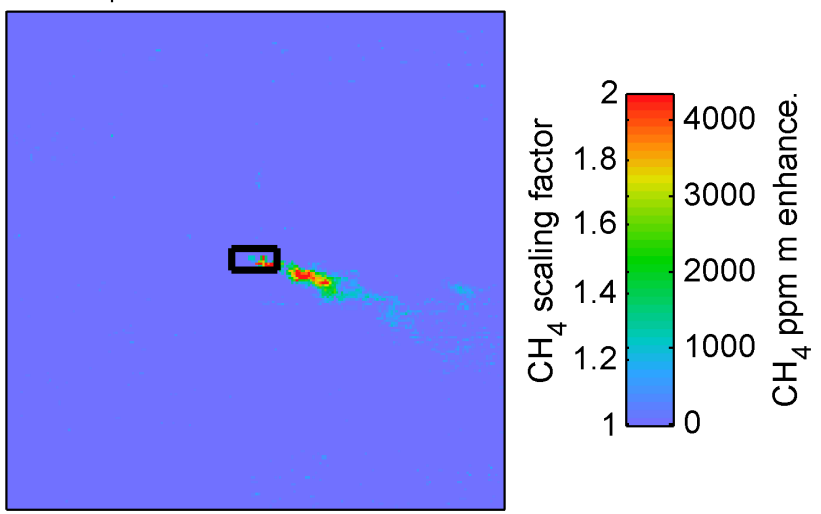

(e) $\mathrm{CH}_{4}: 21$ April 2015, 17:04:17 UTC

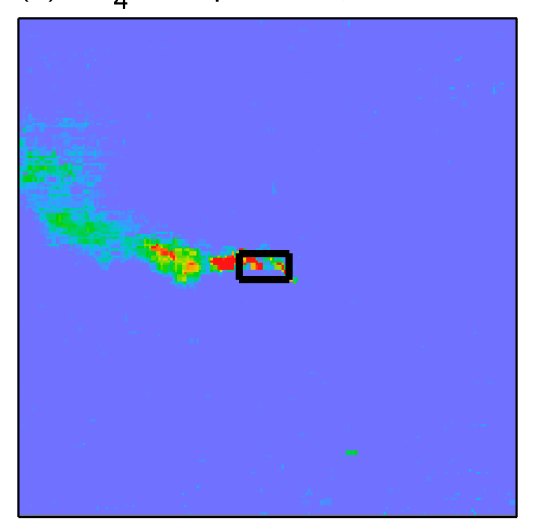

Figure A2. (a) AVIRIS-NG true color image subset from 19 April 2015. (b) Prominent $\mathrm{CH}_{4}$ plume visible from location indicated by the black box. (c) Close-up of 19 April 2015 AVIRIS-NG true color image. (d) Higher-resolution Google Earth imagery indicates the emission source is a tank. (e) Scene from 21 April 2015 indicates a $\mathrm{CH}_{4}$ plume from the same source with an different orientation due to changes in wind direction. For all images, north is up. A thermal camera video for this source is shown in Video A1. 


\section{$\mathrm{A3} \quad \mathrm{CH}_{4}$ emissions from pipeline leak}

(a) 19 April 2015, 18:35:12 UTC

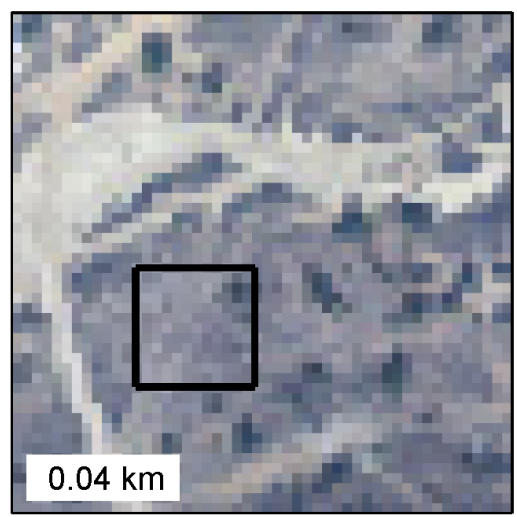

(c) 19 April 2015, 18:35:12 UTC

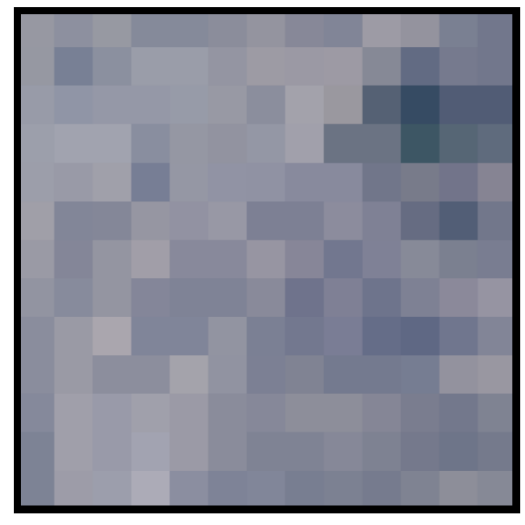

(b) $\mathrm{CH}_{4}: 19$ April 2015, 18:35:12 UTC
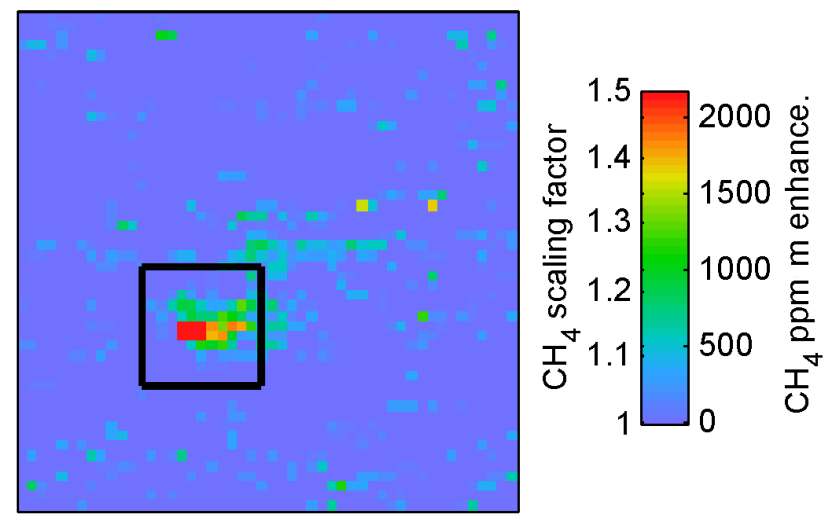

(d) Google Earth: 15 March 2015

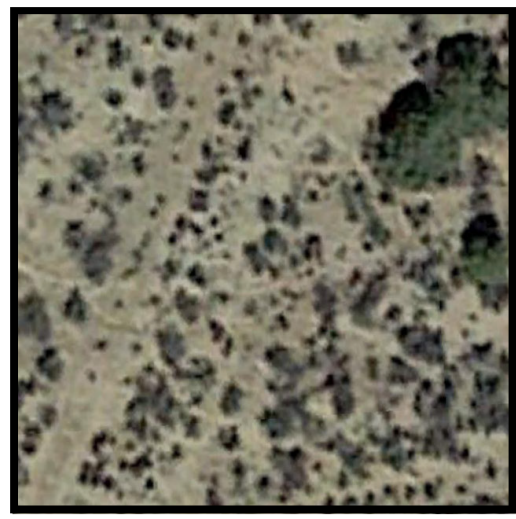

Figure A3. (a) AVIRIS-NG true color image subset. (b) $\mathrm{A} \mathrm{CH}_{4}$ plume is visible for a confirmed leak from a buried natural gas pipeline. (c) Close-up of AVIRIS-NG true color image. (d) Higher-resolution Google Earth imagery does not indicate visible infrastructure. For all images, north is up. A thermal camera video for this source is shown in Video A2. 


\section{A4 $\mathrm{CO}_{2}$ and $\mathrm{H}_{2} \mathrm{O}$ emissions from power plant}

(a) 12 Sep 2014, 19:23:59 UTC

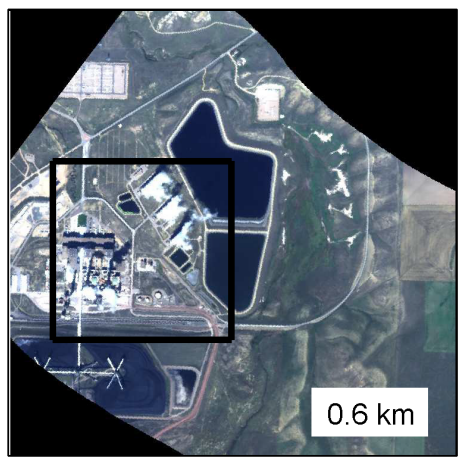

(c) $\mathrm{CH}_{4}: 12$ Sep 2014, 19:23:59 UTC (b) $\mathrm{CO}_{2}: 12$ Sep $2014,19: 23: 59$ UTC

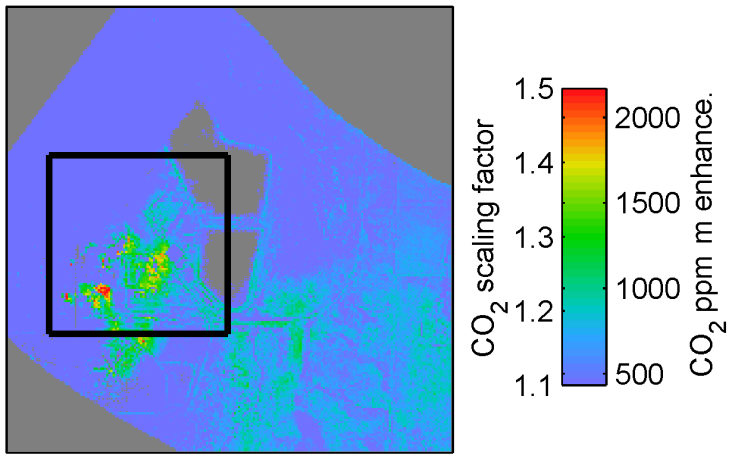

(d) $\mathrm{H}_{2} \mathrm{O}: 12$ Sep 2014, 19:23:59 UTC
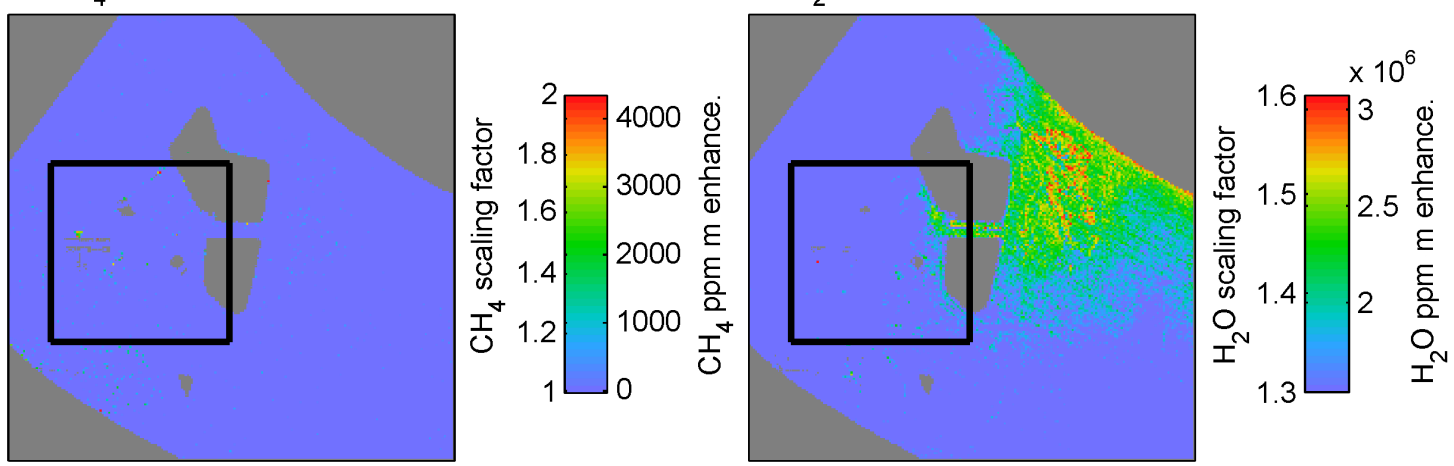

Figure A4. (a) AVIRIS-NG true color image subset. (b) $\mathrm{CO}_{2}$ plumes are visible emanating from flue-gas stacks. (c) $\mathrm{CH}_{4}$ retrieval results. (d) $\mathrm{H}_{2} \mathrm{O}$ plume visible from cooling towers (see Fig. A5). For all images, north is up.

(a) 12 Sep 2014, 19:23:59 UTC

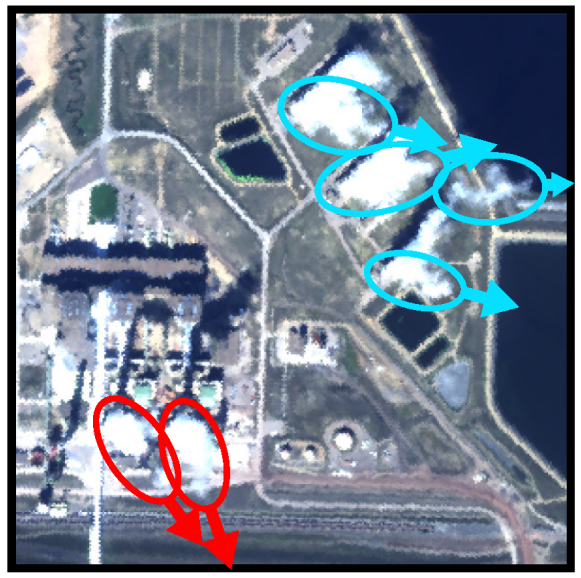

(b) Google Earth: 2 Sep 2014

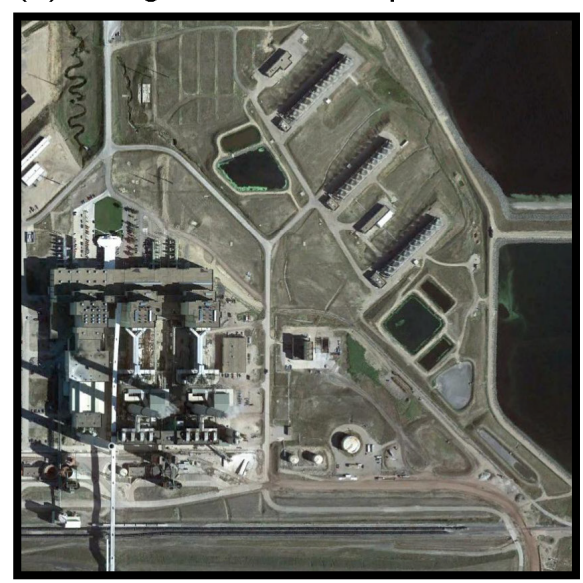

Figure A5. (a) AVIRIS-NG true color image for close-up indicated by black box in Fig. A4. Flue-gas stacks visible in lower left as $\mathrm{CO}_{2}$ sources and cooling towers in upper right as $\mathrm{H}_{2} \mathrm{O}$ sources. Ellipses delineate shapes of plumes visible in true color images for the flue-gas stacks (red) and cooling towers (blue). The arrows indicate winds to the southeast for the flue-gas stacks (consistent with $\mathrm{CO}_{2}$ plumes in Fig. A4b) and to the east for the cooling towers (consistent with $\mathrm{H}_{2} \mathrm{O}$ plumes in Fig. A4d). (b) Higher-resolution Google Earth imagery clearly indicates the flue-gas stacks are much taller than the cooling towers based on assessment of shadows. For both images, north is up. 


\section{The Supplement related to this article is available online at https://doi.org/10.5194/amt-10-3833-2017-supplement.}

Author contributions. CF and AKT designed research; CF, ADA, AKT, DRT, BDB, ROG, EAK, CS and SC provided flight campaign support; AKT, CF, DRT, KG, TK and JB performed research; RMD, ROG, KG, TK, JB, DAR and PED advised the research; AKT and $\mathrm{CF}$ analyzed data and wrote the paper.

Competing interests. The authors declare that they have no conflict of interest.

Acknowledgements. The authors thank NASA HQ and Jack Kaye for funding the flight campaign. We would like to acknowledge the contributions of the AVIRIS-NG flight and instrument teams, including Michael Eastwood, Sarah Lundeen, Ian Mccubin, Mark Helmlinger, Scott Nolte, and Betina Pavri. We would also like to thank Simon Hook and Bill Johnson for their support and for the use of the thermal camera. This work was undertaken in part at the Jet Propulsion Laboratory, California Institute of Technology, under contract with NASA.

Edited by: Andreas Hofzumahaus

Reviewed by: two anonymous referees

\section{References}

Aubrey, A., Frankenberg, C., Green, R., Eastwood, M., Thompson, D., and Thorpe, A.: Crosscutting Airborne Remote Sensing Technologies for Oil and Gas and Earth Science Applications, Offshore Technology Conference, Offshore Technology Conference, 4-7 May, Houston, Texas, USA, https://doi.org/10.4043/25984-MS, 2015.

Ballantyne, A. P., Andres, R., Houghton, R., Stocker, B. D., Wanninkhof, R., Anderegg, W., Cooper, L. A., DeGrandpre, M., Tans, P. P., Miller, J. B., Alden, C., and White, J. W. C.: Audit of the global carbon budget: estimate errors and their impact on uptake uncertainty, Biogeosciences, 12, 2565-2584, https://doi.org/10.5194/bg-12-2565-2015, 2015.

Bovensmann, H., Burrows, J. P., Buchwitz, M., Frerick, J., Noel, S., Rozanov, V. V., Chance, K. V., and Goede, A. P. H.: SCIAMACHY: mission objectives and measurement modes, J. Atmos. Sci., 56, 127-150, https://doi.org/10.1175/15200469(1999)056<0127:SMOAMM>2.0.CO;2, 1999.

Brandt, A. R., Heath, G. A., Kort, E. A., O'Sullivan, F., Pétron, G., Jordaan, S. M., Tans, P., Wilcox, J., Gopstein, A. M., Arent, D., Wofsy, S., Brown, N. J., Bradley, R., Stucky, G. D., Eardley, D., and Harriss, R.: Methane leaks from North American natural gas systems, Science, 343, 733-735, https://doi.org/10.1126/science.1247045, 2014.

Brandt, A. R., Heath, G. A., and Cooley, D.: Methane leaks from natural gas systems follow extreme dis- tributions, Environ. Sci. Technol., 50, 12512-12520, https://doi.org/10.1021/acs.est.6b04303, 2016.

Caulton, D. R., Shepson, P. B., Santoro, R. L., Sparks, J. P., Howarth, R. W., Ingraffea, A. R., Cambaliza, M. O. L., Sweeney, C., Karion, A., Davis, K. J., Stirm, B. H., Montzka, S. A., and Miller, B. R.: Toward a better understanding and quantification of methane emissions from shale gas development, P. Natl. Acad. Sci. USA, 111, 6237-6242, https://doi.org/10.1073/pnas.1316546111, 2014.

Ciais, P., Crisp, D., van der Gron, H. D., Engelen, R., JanssensMaenhout, G., Heimann, M., Rayner, P., and Scholze, M. Towards a European operational observing system to monitor fossil $\mathrm{CO}_{2}$ emissions, Final report from the expert group, Tech. Rep., European Comission, Brussels, Belgium, http://www.copernicus.eu/sites/default/files/library/CO2 Report_22Oct2015.pdf, 2015.

Conley, S., Franco, G., Faloona, I., Blake, D. R., Peischl, J., and Ryerson, T. B.: Methane emissions from the 2015 Aliso Canyon blowout in Los Angeles, CA, Science, 351, 1317-1320, https://doi.org/10.1126/science.aaf2348, 2016.

Dennison, P. E., Thorpe, A. K., Pardyjak, E. R., Roberts, D. A., Qi, Y., Green, R. O., Bradley, E. S., and Funk, C. C.: High spatial resolution mapping of elevated atmospheric carbon dioxide using airborne imaging spectroscopy: Radiative transfer modeling and power plant plume detection, Remote Sens. Environ., 139, 116129, https://doi.org/10.1016/j.rse.2013.08.001, 2013.

Deschamps, A., Marion, R., Briottet, X., Foucher, P., and Lavigne, C.: Simultaneous $\mathrm{CO}_{2}$ and Aerosol Retrieval in a Vegetation Fire Plume Using AVIRIS Hyperspectral Data, 2011 3rd Workshop on. IEEE, Lisbon, Portugal, https://doi.org/10.1109/WHISPERS.2011.6080896, 2011.

EIA: US Energy Information Administraton, EIA annual energy outlook 2013, Tech. rep., US Energy Information Administraton, Washington, DC, United States, available at: https://www. eia.gov/outlooks/aeo/pdf/0383(2013).pdf (last access: 10 May 2017), 2013.

EIA: US Energy Information Administraton, Top 100 US oil and gas fields, Tech. rep., US Energy Information Administraton, U.S. Department of Energy, Washington, DC 20585, available at: https://www.eia.gov/naturalgas/crudeoilreserves/top100/ pdf/top100.pdf (last access: 10 May 2017), 2015.

EPA: US Environmental Protection Agency, Inventory of US Greenhouse Gas Emissions and Sinks: 1990-2014, Technical Report EPA 430-R-16-002 (Environmental Protection Agency), Tech. rep., US Environmental Protection Agency, 2016a.

EPA: US Environmental Protection Agency, 2015 Greenhouse Gas Emissions from Large Facilities, Tech. rep., US Environmental Protection Agency, available at: https://ghgdata.epa.gov/ (last access: 10 May 2017), 2016b.

Frankenberg, C., Platt, U., and Wagner, T.: Iterative maximum a posteriori (IMAP)-DOAS for retrieval of strongly absorbing trace gases: Model studies for $\mathrm{CH}_{4}$ and $\mathrm{CO}_{2}$ retrieval from near infrared spectra of SCIAMACHY onboard ENVISAT, Atmos. Chem. Phys., 5, 9-22, https://doi.org/10.5194/acp-5-92005, 2005.

Frankenberg, C., Thorpe, A. K., Thompson, D. R., Hulley, G., Kort, E. A., Vance, N., Borchardt, J., Krings, T., Gerilowski, K., Sweeney, C., Conley, S., Bue, B. D., Aubrey, A. D., Hook, S., and Green, R. O.: Airborne methane remote mea- 
surements reveal heavy-tail flux distribution in Four Corners region, P. Natl. Acad. Sci. USA, 113, 9734-9739, https://doi.org/10.1073/pnas.1605617113, 2016.

Galfalk, M., Olofsson, G., Crill, P., and Bastviken, D.: Making methane visible, Nature Climate Change, 6, 426-430, https://doi.org/10.1038/nclimate2877, 2016.

Gao, B. C. and Goetz, A. F. H.: Column atmospheric water-vapor and vegetation liquid water retrievals from airborne imaging spectrometer data, J. Geophys. Res.-Atmos., 95, 3549-3564, https://doi.org/10.1029/JD095iD04p03549, 1990.

Gerilowski, K., Tretner, A., Krings, T., Buchwitz, M., Bertagnolio, P. P., Belemezov, F., Erzinger, J., Burrows, J. P., and Bovensmann, H.: MAMAP - a new spectrometer system for column-averaged methane and carbon dioxide observations from aircraft: instrument description and performance analysis, Atmos. Meas. Tech., 4, 215-243, https://doi.org/10.5194/amt-4215-2011, 2011.

Green, R. O., Eastwood, M. L., Sarture, C. M., Chrien, T. G., Aronsson, M., Chippendale, B. J., Faust, J. A., Pavri, B. E., Chovit, C. J., Solis, M. S., Olah, M. R., and Williams, O.: Imaging spectroscopy and the Airborne Visible Infrared Imaging Spectrometer (AVIRIS), Remote Sens. Environ., 65, 227-248, https://doi.org/10.1016/S0034-4257(98)00064-9, 1998.

Hamlin, L., Green, R., Mouroulis, P., Eastwood, M., Wilson, D., Dudik, M., and Paine, C.: Imaging Spectrometer Science Measurements for Terrestrial Ecology: AVIRIS and New Developments, Aerospace Conference, 2011 IEEE, Big Sky, MT, United States, https://doi.org/10.1109/AERO.2011.5747395, 2011.

Hopkins, F. M., Kort, E. A., Bush, S. E., Ehleringer, J. R., Lai, C. T., Blake, D. R., and Randerson, J. T.: Spatial patterns and source attribution of urban methane in the Los Angeles Basin, J. Geophys. Res.-Atmos., 121, 2490-2507, https://doi.org/10.1002/2015JD024429, 2016.

Hulley, G. C., Duren, R. M., Hopkins, F. M., Hook, S. J., Vance, N., Guillevic, P., Johnson, W. R., Eng, B. T., Mihaly, J. M., Jovanovic, V. M., Chazanoff, S. L., Staniszewski, Z. K., Kuai, L., Worden, J., Frankenberg, C., Rivera, G., Aubrey, A. D., Miller, C. E., Malakar, N. K., Sánchez Tomás, J. M., and Holmes, K. T.: High spatial resolution imaging of methane and other trace gases with the airborne Hyperspectral Thermal Emission Spectrometer (HyTES), Atmos. Meas. Tech., 9, 2393-2408, https://doi.org/10.5194/amt-9-2393-2016, 2016.

Jackson, R. B., Down, A., Phillips, N. G., Ackley, R. C., Cook, C. W., Plata, D. L., and Zhao, K. G.: Natural gas pipeline leaks across Washington, DC, Environ. Sci. Technol., 48, 20512058, https://doi.org/10.1021/es404474x, 2014.

Johnson, D. R., Covington, A. N., and Clark, N. N.: Methane Emissions from leak and loss audits of natural gas compressor stations and storage facilities, Environ. Sci. Technol., 49, 8132-8138, https://doi.org/10.1021/es506163m, 2015.

Kalnay, E., Kanamitsu, M., Kistler, R., Collins, W., Deaven, D., Gandin, L., Iredell, M., Saha, S., White, G., Woollen, J., Zhu, Y., Chelliah, M., Ebisuzaki, W., Higgins, W., Janowiak, J., Mo, K. C., Ropelewski, C., Wang, J., Leetmaa, A., Reynolds, R., Jenne, R., and Joseph, D.: The NCEP/NCAR 40-year reanalysis project, B. Am. Meteorol. Soc., 77, 437-471, https://doi.org/10.1175/15200477(1996)077<0437:TNYRP>2.0.CO;2, 1996.
Karion, A., Sweeney, C., Petron, G., Frost, G., Hardesty, R. M., Kofler, J., Miller, B. R., Newberger, T., Wolter, S., Banta, R., Brewer, A., Dlugokencky, E., Lang, P., Montzka, S. A., Schnell, R., Tans, P., Trainer, M., Zamora, R., and Conley, S.: Methane emissions estimate from airborne measurements over a western United States natural gas field, Geophys. Res. Lett., 40, 4393-4397, https://doi.org/10.1002/grl.50811, 2013.

Kirschke, S., Bousquet, P., Ciais, P., Saunois, M., Canadell, J. G., Dlugokencky, E. J., Bergamaschi, P., Bergmann, D., Blake, D. R., Bruhwiler, L., Cameron-Smith, P., Castaldi, S., Chevallier, F., Feng, L., Fraser, A., Heimann, M., Hodson, E. L., Houweling, S., Josse, B., Fraser, P. J., Krummel, P. B., Lamarque, J. F., Langenfelds, R. L., Le Quere, C., Naik, V., O’Doherty, S., Palmer, P. I., Pison, I., Plummer, D., Poulter, B., Prinn, R. G., Rigby, M., Ringeval, B., Santini, M., Schmidt, M., Shindell, D. T., Simpson, I. J., Spahni, R., Steele, L. P., Strode, S. A., Sudo, K., Szopa, S., van der Werf, G. R., Voulgarakis, A., van Weele, M., Weiss, R. F., Williams, J. E., and Zeng, G.: Three decades of global methane sources and sinks, Nat. Geosci., 6, 813-823, https://doi.org/10.1038/ngeo1955, 2013.

Kneizys, F. X., Abreu, L. W., Anderson, G. P., Chetwynd, J. H., Shettle, E. P., Robertson, D. C., Acharya, P., Rothman, L., Selby, J. E. A., Gallery, W. O., and Clough, S. A.: The MODTRAN 2/3 report and LOWTRAN 7 model, Tech. rep., Phillips Laboratory, Geophysics Directorate, Andover, MA, United States, 1996.

Kort, E. A., Frankenberg, C., Costigan, K. R., Lindenmaier, R., Dubey, M. K., and Wunch, D.: Four corners: the largest US methane anomaly viewed from space, Geophys. Res. Lett., 41, 6898-6903, https://doi.org/10.1002/2014GL061503, 2014.

Krautwurst, S., Gerilowski, K., Jonsson, H. H., Thompson, D. R., Kolyer, R. W., Iraci, L. T., Thorpe, A. K., Horstjann, M., Eastwood, M., Leifer, I., Vigil, S. A., Krings, T., Borchardt, J., Buchwitz, M., Fladeland, M. M., Burrows, J. P., and Bovensmann, H.: Methane emissions from a Californian landfill, determined from airborne remote sensing and in situ measurements, Atmos. Meas. Tech., 10, 3429-3452, https://doi.org/10.5194/amt10-3429-2017, 2017.

Krings, T., Gerilowski, K., Buchwitz, M., Reuter, M., Tretner, A., Erzinger, J., Heinze, D., Pflüger, U., Burrows, J. P., and Bovensmann, H.: MAMAP - a new spectrometer system for column-averaged methane and carbon dioxide observations from aircraft: retrieval algorithm and first inversions for point source emission rates, Atmos. Meas. Tech., 4, 1735-1758, https://doi.org/10.5194/amt-4-1735-2011, 2011.

Krings, T., Gerilowski, K., Buchwitz, M., Hartmann, J., Sachs, T., Erzinger, J., Burrows, J. P., and Bovensmann, H.: Quantification of methane emission rates from coal mine ventilation shafts using airborne remote sensing data, Atmos. Meas. Tech., 6, 151-166, https://doi.org/10.5194/amt-6-151-2013, 2013.

Kuai, L., Worden, J. R., Li, K.-F., Hulley, G. C., Hopkins, F. M., Miller, C. E., Hook, S. J., Duren, R. M., and Aubrey, A. D.: Characterization of anthropogenic methane plumes with the Hyperspectral Thermal Emission Spectrometer (HyTES): a retrieval method and error analysis, Atmos. Meas. Tech., 9, 3165-3173, https://doi.org/10.5194/amt-9-3165-2016, 2016.

Lavoie, T. N., Shepson, P. B., Cambaliza, M. O. L., Stirm, B. H., Karion, A., Sweeney, C., Yacovitch, T. I., Herndon, S. C., Lan, X., and Lyon, D.: Aircraft-based 
measurements of point source methane emissions in the Barnett Shale Basin, Environ. Sci. Technol., 49, 7904-7913, https://doi.org/10.1021/acs.est.5b00410, 2015.

LTE: 2015 Fruitland outcrop monitoring report, La Plata County, Colorado, Tech. rep., LT Environmental, Inc., available at: http://cogcc.state.co.us/ documents/library/AreaReports/SanJuanBasin/3m_project/ 2015FRUITLANDOUTCROPMONITORINGREPORT_La_ Plata.pdf, (last access: 5 January 2017), 2015.

Lyon, D. R., Zavala-Araiza, D., Alvarez, R. A., Harriss, R., Palacios, V., Lan, X., Talbot, R., Lavoie, T., Shepson, P., Yacovitch, T. I., Herndon, S. C., Marchese, A. J., Zimmerle, D., Robinson, A. L., and Hamburg, S. P.: Constructing a spatially resolved methane emission inventory for the Barnett Shale Region, Environ. Sci. Technol., 49, 8147-8157, https://doi.org/10.1021/es506359c, 2015.

Marion, R., Michel, W., and Faye, C.: Measuring trace gases in plumes from hyperspectral remotely sensed data, IEEE T. Geosci. Remote, 42, 854-864, https://doi.org/10.1109/TGRS.2003.820604, 2004.

Miller, S., Wofsy, S., Michalak, A., Kort, E. A., Andrews, A., Biraud, S., Dlugockenky, E. J., Eluszkiewicz, J., Fisher, M., Janssens-Maenhout, G., Miller, B., Miller, J., Montzka, S., Nehrkorn, T., and Sweeney, C.: Anthropogenic emissions of methane in the United States, P. Natl. Acad. Sci. USA, 110, https://doi.org/10.1073/pnas.1314392110, 2013.

Myhre, G., Shindell, D., Bréon, F.-M., Collins, W., Fuglestvedt, J., Huang, J., Koch, D., Lamarque, J., Lee, D., Mendoza, B., Nakajima, T., Robock, A., Stephens, G., Takemura, T., and Zhang, H.: Anthropogenic and natural radiative forcing, in: Climate Change 2013: The Physical Science Basis. Contribution of Working Group I to the Fifth Assessment Report of the Intergovernmental Panel on Climate Change, Tech. rep., Intergovernmental Panel on Climate Change, 423, 658-740, 2013.

Nisbet, E. G., Dlugokencky, E. J., and Bousquet, P.: Methane on the rise-again, Science, 343, 493-495, https://doi.org/10.1126/science.1247828, 2014.

NOAA: GMD measurement locations, National Oceanic and Atmospheric Administration (NOAA), Earth System Research Laboratory, Global Monitoring Division, Tech. rep., National Oceanic and Atmospheric Administration, 2015.

NRC: National Research Council committee on methods for estimating greenhouse gas emissions; Verifying greenhouse gas emissions: Methods to support international climate agreements, The National Academies Press, Washington, D. C., 2010.

Ogunjemiyo, S., Roberts, D. A., Keightley, K., Ustin, S. L., Hinckley, T., and Lamb, B.: Evaluating the relationship between AVIRIS water vapor and poplar plantation evapotranspiration, J. Geophys. Res.-Atmos., 107, 4719, https://doi.org/10.1029/2001JD001194, 2002.

Phillips, N. G., Ackley, R., Crosson, E. R., Down, A., Hutyra, L. R., Brondfield, M., Karr, J. D., Zhao, K. G., and Jackson, R. B.: Mapping urban pipeline leaks: methane leaks across Boston, Environ. Pollut., 173, 1-4, https://doi.org/10.1016/j.envpol.2012.11.003, 2013.

Rella, C. W., Tsai, T. R., Botkin, C. G., Crosson, E. R., and Steele, D.: Measuring emissions from oil and natural gas well pads using the mobile flux plane technique, Environ. Sci. Tech- nol., 49, 4742-4748, https://doi.org/10.1021/acs.est.5b00099, 2015.

Roberts, D. A., Bradley, E. S., Cheung, R., Leifer, I., Dennison, P. E., and Margolis, J. S.: Mapping methane emissions from a marine geological seep source using imaging spectrometry, Remote Sens. Environ., 114, 592-606, https://doi.org/10.1016/j.rse.2009.10.015, 2010.

Rodgers, C. D.: Inverse Methods for Atmospheric Sounding, Theory and Practice, World Scientific, London, 2000.

Rothman, L. S., Gordon, I. E., Barbe, A., Benner, D. C., Bernath, P. E., Birk, M., Boudon, V., Brown, L. R., Campargue, A., Champion, J. P., Chance, K., Coudert, L. H., Dana, V., Devi, V. M., Fally, S., Flaud, J. M., Gamache, R. R., Goldman, A., Jacquemart, D., Kleiner, I., Lacome, N., Lafferty, W. J., Mandin, J. Y., Massie, S. T., Mikhailenko, S. N., Miller, C. E., Moazzen-Ahmadi, N., Naumenko, O. V., Nikitin, A. V., Orphal, J., Perevalov, V. I., Perrin, A., Predoi-Cross, A., Rinsland, C. P., Rotger, M., Simeckova, M., Smith, M. A. H., Sung, K., Tashkun, S. A., Tennyson, J., Toth, R. A., Vandaele, A. C., and Vander Auwera, J.: The HITRAN 2008 molecular spectroscopic database, J. Quant. Spectrosc. Ra., 110, 533572, https://doi.org/10.1016/j.jqsrt.2009.02.013, 2009.

Schaefer, H., Mikaloff Fletcher, S. E., Veidt, C., Lassey, K. R., Brailsford, G. W., Bromley, T. M., Dlugokencky, E. J., Michel, S. E., Miller, J. B., Levin, I., Lowe, D. C., Martin, R. J., Vaughn, B. H., and White, J. W. C.: A 21st century shift from fossil-fuel to biogenic methane emissions indicated by ${ }^{13} \mathrm{CH}_{4}$, Science, 352, 80-84, https://doi.org/10.1126/science.aad2705, 2016.

Schwietzke, S., Sherwood, O. A., Bruhwiler, L. M. P., Miller, J. B., Etiope, G., Dlugokencky, E. J., Michel, S. E., Arling, V. A., Vaughn, B. H., White, J. W. C., and Tans, P. P.: Upward revision of global fossil fuel methane emissions based on isotope database, Nature, 538, 88-91, https://doi.org/10.1038/nature19797, 2016.

Smith, M. L., Kort, E. A., Karion, A., Sweeney, C., Herndon, S. C., and Yacovitch, T. I.: Airborne ethane observations in the Barnett Shale: quantification of ethane flux and attribution of methane emissions, Environ. Sci. Technol., 49, 8158-8166, https://doi.org/10.1021/acs.est.5b00219, 2015.

Thompson, D. R., Gao, B. C., Green, R. O., Dennison, P. E., Roberts, D. A., and Lundeen, S.: Atmospheric correction for global mapping spectroscopy: advances for the HyspIRI preparatory campaign, Remote Sens. Environ., 167, 64-77, https://doi.org/10.1016/j.rse.2015.02.010, 2015a.

Thompson, D. R., Leifer, I., Bovensmann, H., Eastwood, M., Fladeland, M., Frankenberg, C., Gerilowski, K., Green, R. O., Kratwurst, S., Krings, T., Luna, B., and Thorpe, A. K.: Real-time remote detection and measurement for airborne imaging spectroscopy: a case study with methane, Atmos. Meas. Tech., 8, 4383-4397, https://doi.org/10.5194/amt-8-4383-2015, 2015 b.

Thompson, D. R., Thorpe, A. K., Frankenberg, C., Green, R. O., Duren, R., Guanter, L., Hollstein, A., Middleton, E., Ong, L., and Ungar, S.: Space-based remote imaging spectroscopy of the Aliso Canyon $\mathrm{CH}_{4}$ superemitter, Geophys. Res. Lett., 43, 65716578, https://doi.org/10.1002/2016GL069079, 2016.

Thorpe, A. K., Frankenberg, C., and Roberts, D. A.: Retrieval techniques for airborne imaging of methane concentrations using high spatial and moderate spectral resolution: 
application to AVIRIS, Atmos. Meas. Tech., 7, 491-506, https://doi.org/10.5194/amt-7-491-2014, 2014.

Thorpe, A. K., Frankenberg, C., Aubrey, A. D., Roberts, D. A., Nottrott, A. A., Rahn, T. A., Sauer, J. A., Dubey, M. K., Costigan, K. R., Arata, C., Steffke, A. M., Hills, S., Haselwimmer, C., Charlesworth, D., Funk, C. C., Green, R. O., Lundeen, S. R., Boardman, J. W., Eastwood, M. L., Sarture, C. M., Nolte, S. H., Mccubbin, I. B., Thompson, D. R., and McFadden, J. P.: Mapping methane concentrations from a controlled release experiment using the next generation airborne visible/infrared imaging spectrometer (AVIRIS-NG), Remote Sens. Environ., 179, 104115, https://doi.org/10.1016/j.rse.2016.03.032, 2016a.

Thorpe, A. K., Frankenberg, C., Green, R. O., Thompson, D. R., Aubrey, A. D., Mouroulis, P., Eastwood, M. L., and Matheou, G.: The Airborne Methane Plume Spectrometer (AMPS): Quantitative imaging of methane plumes in real time, 2016 IEEE Aerospace Conference, https://doi.org/10.1109/AERO.2016.7500756, 2016b.

Thorpe, A. K. and Krohn, J.: Video showing methane plume from tank obtained using ground-based thermal camera, Copernicus Publications, https://doi.org/10.5446/30884, 2017a.

Thorpe, A. K. and Krohn, J.: Video showing methane plume from buried natural gas pipeline obtained using ground-based thermal camera, Copernicus Publications, https://doi.org/10.5446/30883, $2017 b$.

Tratt, D. M., Buckland, K. N., Hall, J. L., Johnson, P. D., Keim, E. R., Leifer, I., Westberg, K., and Young, S. J.: Airborne visualization and quantification of discrete methane sources in the environment, Remote Sens. Environ., 154, 74-88, https://doi.org/10.1016/j.rse.2014.08.011, 2014.

TRI: Tri-State Generation and Transmission Association, Tech. rep., Tri-State Generation and Transmission Association, available at: http://www.tsgt.coop/AboutUs/baseload-resources.cfm (last access: 10 May 2017), 2016.
Turner, A. J., Jacob, D. J., Wecht, K. J., Maasakkers, J. D., Lundgren, E., Andrews, A. E., Biraud, S. C., Boesch, H., Bowman, K. W., Deutscher, N. M., Dubey, M. K., Griffith, D. W. T., Hase, F., Kuze, A., Notholt, J., Ohyama, H., Parker, R., Payne, V. H., Sussmann, R., Sweeney, C., Velazco, V. A., Warneke, T., Wennberg, P. O., and Wunch, D.: Estimating global and North American methane emissions with high spatial resolution using GOSAT satellite data, Atmos. Chem. Phys., 15, 7049-7069, https://doi.org/10.5194/acp-15-7049-2015, 2015.

Wecht, K. J., Jacob, D. J., Frankenberg, C., Jiang, Z., and Blake, D. R.: Mapping of North American methane emissions with high spatial resolution by inversion of SCIAMACHY satellite data, J. Geophys. Res.-Atmos., 119, 77417756, https://doi.org/10.1002/2014JD021551, 2014.

Williams: NASA study shows one detection of methane in multiple surveys of Ignacio plant, Tech. rep., Williams Partners, L. P., available at: https://blog.williams.com/projectsand-operations/nasa-study-shows-no-detection-of-methane-inmultiple (last access: 10 May 2017) 2016.

Zavala-Araiza, D., Lyon, D., Alvarez, R. A., Palacios, V., Harriss, R., Lan, X., Talbot, R., and Hamburg, S. P.: Toward a functional definition of methane super-emitters: Application to natural gas production sites, Environ. Sci. Technol., 49, 8167-8174, https://doi.org/10.1021/acs.est.5b00133, 2015. 